\title{
Enantiomeric Amino Acid Schiff Base Copper(II) Complexes as a New Class of RNA-Targeted Metallo-Intercalators: Single X-ray Crystal Structural Details, Comparative in Vitro DNA/RNA Binding Profile, Cleavage, and Cytotoxicity
}

\author{
Siffeen Zehra, ${ }^{\dagger}$ Thierry Roisnel, ${ }^{\dagger}$ and Farukh Arjmand ${ }^{*},^{\dagger} \odot$ \\ ${ }^{\dagger}$ Department of Chemistry Aligarh Muslim University, Aligarh, Uttar Pradesh 202002, India \\ ${ }^{\ddagger}$ Institut des Sciences Chimiques de Rennes, UMR 6226, Université de Rennes 1, Campus de Beaulieu Batiment 10B, Bureau, \\ Rennes 15335042, France
}

Supporting Information

\begin{abstract}
Chiral enantiomeric amino acid Schiff base copper(II) complexes $\mathbf{1}$ and $\mathbf{2}$ (a and $\mathbf{b}$ ) were synthesized and characterized by various spectroscopic techniques (Fourier transform infrared, UV-vis, electron paramagnetic resonance, electrospray ionization-mass spectrometry, and circular dichroism) and single X-ray crystal diffraction analyses. To understand the selectivity and enantiomeric behavior of the complexes, binding interaction with ct-DNA and tRNA biomolecules was investigated by widely employed optical and hydrodynamic techniques. The binding experiments demonstrated that complexes $\mathbf{1}$ and $\mathbf{2}$ ( $\mathbf{a}$ and $\mathbf{b}$ ) interact strongly via the intercalative mode with preferential binding

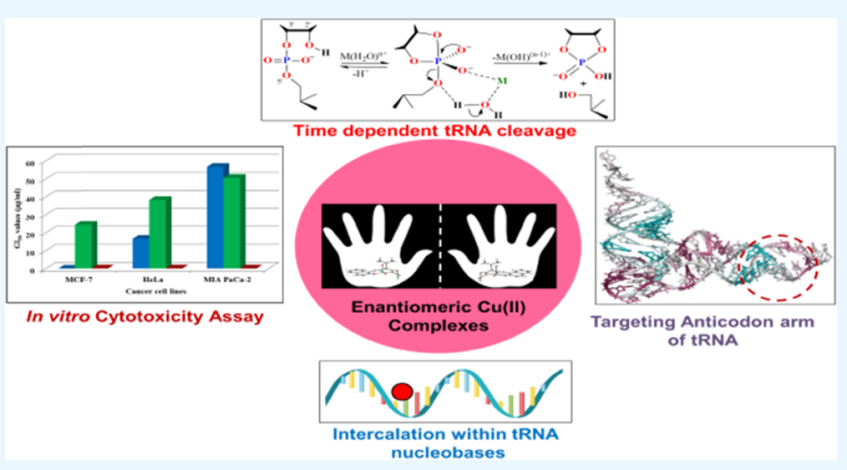
toward the tRNA biomolecule compared to ct-DNA. Furthermore, the order of binding propensity was $\mathbf{2} \mathbf{a}>\mathbf{2} \mathbf{b}>\mathbf{1 a}>\mathbf{1 b}$, implicating greater binding affinity of L-enantiomeric complexes, and complex $2 \mathrm{a}$ showed the highest binding propensity possessing a rigid aromatic group in the amino acid framework. Scanning electron microscopy analyses of complexes 1a and 2a revealed the formation of different morphologies with ct-DNA/tRNA molecules depending on the nature and extent of condensation induced by the complexes. The cleavage activities of complexes $\mathbf{1 a}$ and $\mathbf{2 a}$ showed a preferential oxidative cleavage mechanism toward the pBR322 plasmid DNA mediated by reactive oxygen species radical scavengers involving singlet oxygen $\left({ }^{1} \mathrm{O}_{2}\right)$ and superoxide anions $\left(\mathrm{O}_{2}{ }^{\bullet-}\right)$. The tRNA cleavage mechanism of complexes $1 \mathrm{a}$ and $2 \mathrm{a}$ revealed time- and concentration-dependent activities of these $\mathrm{Schiff}$ base $\mathrm{Cu}(\mathrm{II})$ complexes. In vitro cytotoxic activities of complexes $\mathbf{1}$ and $\mathbf{2}$ (a and $\mathbf{b}$ ) revealed that among all, complex $\mathbf{2 a}$ showed the highest cytotoxicity, being selectively targeted toward the human breast cancer cell line (MCF-7) with a GI $\mathrm{G}_{50}$ value of $<1 \mu \mathrm{M}$. The results suggest that the L-enantiomeric complexes are more avid binders toward the tRNA molecule and showed better cytotoxicity.
\end{abstract}

\section{INTRODUCTION}

According to the World Health Organization (WHO), cancer is the leading cause of global mortality, accounting for 7.6 million deaths in 2008 and is expected to exponentially rise to 13.1 million deaths in 2030. ${ }^{1}$ This draws the attention of researchers to pressing demands for searching newer metallotherapeutic drugs for the treatment of cancers with more advantageous features as compared to the parent antitumor drug cisplatin, cis-diamminedichloroplatinum(II). ${ }^{2}$ One of the main challenges of cisplatin is the systemic toxicity and resistance issue, which can lead to many adverse side effects in patients administered with this drug. 3,4

Since most of the classical anticancer therapeutics in the drug regime for cancers are known to act by targeting DNA, researchers in the area of medicinal chemistry realized that RNA, its chemical cousin, could prove a more fruitful and promising therapeutic target. RNAs can be exploited as drug targets due to the absence of the cellular repair mechanism, ${ }^{6}$ their unique structural polymorphism, ${ }^{7}$ and their capability to "switch" between single-stranded and double-stranded forms. ${ }^{8}$ Besides this, RNAs can fold into intricate three-dimensional (3D) secondary and tertiary structures that provide recognition domains to a large variety of molecular targets to which RNAs can bind with high affinity and specificity. ${ }^{9}$ Moreover, RNA is well suited for dynamic, transient expression from being transcriptionally inactive to fully functional. In addition, as conformational changes can be triggered by ligand binding or small therapeutic molecules, RNA structures themselves can

Received: January 15, 2019

Accepted: April 15, 2019

Published: April 26, 2019 
Scheme 1. Synthetic Scheme for the Preparation of Complexes 1 and 2 (a and b)

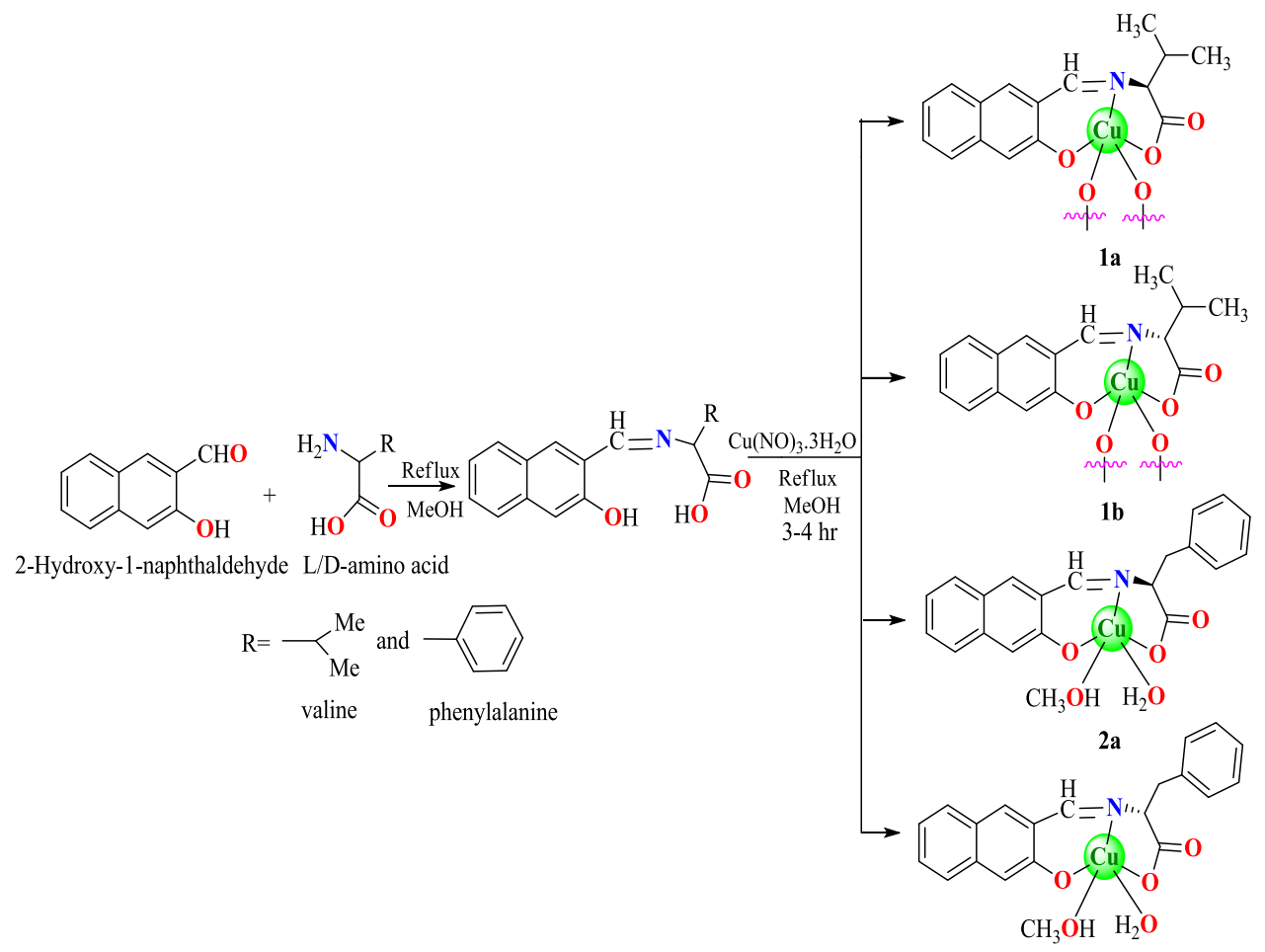

$\mathbf{2 b}$

be very dynamic. ${ }^{10} \mathrm{X}$-ray analysis has revealed that in the Aform configuration of RNA having an L-shaped tertiary structure, nucleic acid bases are pushed outward from the helix axis in the minor groove direction and tilted substantially with respect to the helix axis. This results in a much shallow and wide minor groove and a major groove that is narrow and pulled deeply into the interior of the molecule. ${ }^{11}$ Therefore, a large number of small molecules can access the minor groove of RNAs and give new mechanistic insights for the treatment of chronic diseases, viz., cancers. Previous literature reports show that RNA-targeted small molecules possess heterocyclic structural scaffolds with planar aromatic moieties capable of intercalation via $\pi-\pi$ stacking between the RNA bases in the specific minor groove sites. ${ }^{12-15}$

RNA is an inherently chiral molecule ${ }^{16}$ that can exhibit complementarity with a single enantiomeric drug candidate (in our case L/D amino acids); consequently, it will result in a more avid and specific interaction at the molecular target site, leading to differential biological response to optical isomers by discriminating between the two enantiomers. Currently, R\&D in drug design is focusing on single enantiomer formulation vs racemic mixture as it shows novelty with safer, better-tolerated, and more efficacious medications for treating patients. ${ }^{17,18}$

Schiff base architecture $(\mathrm{HC}=\mathrm{N})$ is a versatile medicinal scaffold, which has shown promise as anti-inflammatory, ${ }^{19}$ antibacterial, $^{20}$ and anticancer agents. ${ }^{21}$ Amino acids are the source of the stereogenic chiral carbon center besides being the basic building blocks of all living organisms. The introduction of chirality via the amino acid ligands could result in the enhancement of the pharmacological behavior of the complexes by adopting a specific conformation and may also offer selective binding affinity toward the chiral biomolecules. $^{22,23}$ Therefore, Schiff base ligands derived from condensation of planar aromatic 2-hydroxy-1-naphthaldehyde with amino acids, namely, L/D-valine and phenylalanine, can elegantly cater to a class of new RNA-targeting drug candidates with much improved pharmacological properties.

In continuation to our previous work on the design and synthesis of metal-based antitumor drug entities, ${ }^{24,25}$ herein we describe the synthesis of four chiral Schiff base amino acid $\mathrm{Cu}$ (II) complexes, which are characterized by various spectroscopic methods and single X-ray diffraction studies. Copper, being a bioessential element, is endowed with many important chemical and biological properties, viz., strong Lewis acid, partially filled d-orbitals, redox-active center, antibacterial, $^{26}$ antioxidant, ${ }^{27}$ antiproliferative, ${ }^{28}$ antimetastatic, $^{29}$ and anticancer; $^{30}$ therefore, chiral copper-based drugs can be considered as a new class of promising antitumor drug candidates. Previous literature reports on copper complexes reveal that copper can reduce a tumors' microvascular supply, the tumor volume, and vascular permeability in different strains of cancers. ${ }^{31}$ Copper complexes lead to cell death (i) by inducing apoptosis (programmed cell death) affecting only cancerous cells while leaving the normal cells unaffected ${ }^{32,33}$ and (ii) by generation of reactive oxygen species (ROS) species in oxidative stress, resulting in DNA damage and strand breaks. $^{34}$ Earlier studies have demonstrated that copper complexes containing planar aromatic groups primarily exhibit an intercalating mode of binding with $\mathrm{DNA}^{35}$ and RNA. ${ }^{36}$ However, there is scarcity of literature on metallated drug entities targeted to RNAs. This work provides a rationale for the design of new RNA-targeted copper-based antitumor therapeutic agents endowed with intercalating ability and can open up avenues to design and develop a wide spectrum of new, more efficacious RNA-targeted antitumor chemotherapeutics. 


\section{RESULTS AND DISCUSSION}

Chiral $\mathrm{N}$-(2-hydroxy-1-naphthylidene) amino acid $\mathrm{Cu}$ (II) complexes $\mathbf{1}$ and $\mathbf{2}$ ( $\mathbf{a}$ and $\mathbf{b}$ ) have been synthesized as depicted in Scheme 1. The structures of complexes 1 and 2 (a and $\mathbf{b}$ ) were established by single X-ray crystallography and various spectroscopic techniques (IR, UV-vis, electron paramagnetic resonance (EPR), and electrospray ionizationmass spectrometry (ESI-MS)). The synthesized complexes were found to be air stable and soluble in methanol, dimethyl sulfoxide (DMSO), and dimethylformamide.

IR and Electronic Spectral Studies. The IR bands corresponding to $\nu(-\mathrm{C}=\mathrm{N})$ vibrations for complexes 1 and 2 (a and $\mathbf{b}$ ) were recorded in the range of 1637-1642 $\mathrm{cm}^{-1}$. The vibration bands of the $-\mathrm{COOH}$ group were found at 1568$1542 \mathrm{~cm}^{-1}$, which could be ascribed to $\nu\left(\mathrm{COO}^{-}\right)_{\text {asym }}$ vibrations, and at $1414-1359 \mathrm{~cm}^{-1}$ for $\nu\left(\mathrm{COO}^{-}\right)_{\text {sym }}$ vibrations with $\Delta \nu\left(\mathrm{COO}^{-}\right) \sim 200 \mathrm{~cm}^{-1}$, indicating the unidentate mode of coordination for the carboxylate group. ${ }^{37}$ Complexes 1 and 2 ( $\mathbf{a}$ and $\mathbf{b}$ ) showed the absorption bands in the region of $1302-1286 \mathrm{~cm}^{-1}$ characteristic of the $\nu(-\mathrm{CO})$ phenolic vibration. The IR spectra of complexes $\mathbf{2 a}$ and $\mathbf{2 b}$ exhibited broad bands at $3470 \mathrm{~cm}^{-1}$ attributed to the $\nu(-\mathrm{OH})$ vibration due to the presence of water molecule in the crystal lattice of the complexes. ${ }^{38}$ Far-IR spectra of the complexes showed bands in the regions $574-550 \mathrm{~cm}^{-1}$ and $486-479 \mathrm{~cm}^{-1}$, which were assigned to $\nu(\mathrm{Cu}-\mathrm{N})$ and $\nu(\mathrm{Cu}-\mathrm{O})$ stretching vibrations, respectively.

The electronic spectra of complexes $\mathbf{1}$ and $\mathbf{2}$ ( $\mathbf{a}$ and $\mathbf{b}$ ) in methanol were recorded in the range of 200-700 $\mathrm{nm}$. Absorption bands in the ultraviolet region attributed to ligand-to-metal charge transfer bands (LMCT) appeared at 371-389 nm. $\mathrm{Cu}(\mathrm{II})$ complexes $\mathbf{1}$ and $\mathbf{2}$ ( $\mathbf{a}$ and $\mathbf{b}$ ) showed absorptions in the lower energy region of 646-655 nm assigned to the ${ }^{2} \mathrm{Eg} \rightarrow{ }^{2} \mathrm{~T}_{2} \mathrm{~g}$ transition corresponding to $\mathrm{d}-\mathrm{d}$ bands, indicating that the complexes possess distorted square pyramidal geometry, ${ }^{39}$ consistent with the X-ray crystallographic structure of the complexes.

The EPR spectra of complexes $\mathbf{1}$ and $\mathbf{2}$ ( $\mathbf{a}$ and $\mathbf{b}$ ) were recorded at room temperature in the polycrystalline state to analyze the coordination environment around the $\mathrm{Cu}$ (II) ion and establish the geometry of the complexes (Figure S1). The EPR spectra of complexes $\mathbf{1}$ ( $\mathbf{a}$ and $\mathbf{b}$ ) exhibited one broad signal having $g_{\|}$at 2.25 and $g_{\perp}$ at 2.08 and 2.06, whereas complexes 2 (a and $\mathbf{b}$ ) revealed $g_{\|}$signals at 2.26 and 2.25 and $g_{\perp}$ at 2.07 , implicating pentacoordinate geometry around the metal atom. The pentacoordinate complexes having $g_{\|}$value greater than $g_{\perp}$ are suggestive of a distorted square pyramidal geometry, ruling out the possibility of trigonal bipyramidal geometry for these complexes. ${ }^{40}$

The mass spectra of the enantiomeric complexes corroborated well with their proposed chemical structures (Figure S2). The ESI-MS spectra of complexes $\mathbf{1 a}$ and $\mathbf{1} \mathbf{b}$ exhibited molecular ion peaks $\left[\mathrm{M}^{+}\right]$at $m / z=332.99$ corresponding to the $\left[\mathrm{C}_{16} \mathrm{H}_{15} \mathrm{CuNO}_{3}\right]^{+}$fragment, which differs only in the relative intensity, and other peaks at 272.07 and 273.07 ascribed to the ligand moieties with molecular fragments $\left[\mathrm{C}_{16} \mathrm{H}_{17} \mathrm{NO}_{3}+\mathrm{H}\right]^{+}$and $\left[\mathrm{C}_{16} \mathrm{H}_{17} \mathrm{NO}_{3}+2 \mathrm{H}\right]^{+}$. For complexes $\mathbf{2 a}$ and $\mathbf{2 b}$, the molecular ion peak for the fragment $\left[\mathrm{C}_{20} \mathrm{H}_{15} \mathrm{CuNO}_{3}\right]^{+}$having different relative intensity was observed at $\mathrm{m} / z=381.01$, whereas additional ion peaks at 320.07 and 320.08 were observed for the ligand moieties having the molecular formula $\left[\mathrm{C}_{20} \mathrm{H}_{17} \mathrm{NO}_{3}+\mathrm{H}\right]^{+}$.
The enantiomeric nature and absolute configuration of complexes $\mathbf{1}$ and $\mathbf{2}$ ( $\mathbf{a}$ and $\mathbf{b}$ ) were ascertained by measuring the circular dichroism (CD) spectra (Figure 1). The circular
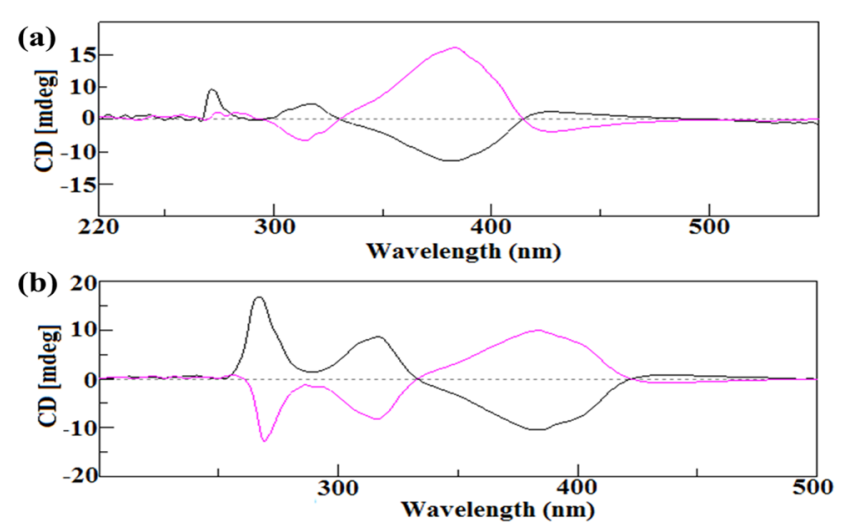

Figure 1. CD spectra of complexes (a) $\mathbf{1 a}$ (black) and $\mathbf{1 b}$ (pink) and (b) $\mathbf{2 a}$ (black) and $\mathbf{2 b}$ (pink) in the methanolic solutions.

dichroism arises due to differential absorption of circularly polarized light, revealing that the chiral enantiomers exhibit opposite cotton effect at similar wavelength. ${ }^{41}$ Complex 1a emitted a positive absorption signal at $316 \mathrm{~nm}$ and a negative signal at $381 \mathrm{~nm}$, whereas complex $\mathbf{1 b}$ revealed absorption peaks in the same wavelength range but with opposite signatures. The enantiomeric complexes $\mathbf{2 a}$ and $\mathbf{2 b}$ showed similar optical features with positive signals at 266 and 316, respectively, and negative signals at $383 \mathrm{~nm}$, depicting opposite cotton effect. These results indicate the existence of a mirror image relationship between complexes $\mathbf{1}$ ( $\mathbf{a}$ and $\mathbf{b}$ ) and 2 (a and $\mathbf{b}$ ) and validate the presence of chiral enantiomers.

Crystal Structure of Complexes 1 and 2 (a and b). Suitable green, thin transparent crystals of complexes $\mathbf{1}$ and $\mathbf{2}$ (a and $\mathbf{b}$ ) were obtained from the mother liquor after slow evaporation at room temperature over a period of 3-4 days. The single X-ray diffraction studies revealed that complexes 1a and $\mathbf{1 b}$ crystallize in the orthorhombic crystal system with the $P 22_{1} 2_{1}$ space group. The $\mathrm{Cu}(\mathrm{II})$ center in complex $\mathbf{1 a}$ adopts a distorted square pyramidal geometry by coordination through the ONO donor set from the tridentate L-valine-2hydroxy-1-naphthaldehyde Schiff base and two other deprotonated carboxylate oxygen atoms of the neighboring ligand moieties, with one of the oxygen atoms occupying the axial position of the pyramid and the other one in the equatorial plane acting as a "bridging atom" between the two perpendicularly arranged copper centers (Figure 2). Complex 1b possesses a similar coordination environment except that the $\mathrm{C} 4$ carbon atom has $R$-configuration, whereas $S$ configuration was found in complex 1a. In the Schiff base ligand, the second carboxylate group remains deprotonated, pointing outside the complex core. Thus, each organic ligand chelates with three $\mathrm{Cu}$ (II) ions in the following modes: two $(\mathrm{O}, \mathrm{O})$ and one $(\mathrm{ONO})$ donor sets; such coordination motifs are found commonly in $\mathrm{Cu}(\mathrm{II})$ chemistry. The carboxylate oxygen atom in the apical position of the pyramid possesses a longer $\mathrm{Cu}-\mathrm{O}$ bond distance $(2.437 \AA)$ compared to those of $\mathrm{Cu}-\mathrm{O}(1.988 \AA$ ) bonds in the basal plane, thus suggesting the presence of the Jahn-Teller effect, which resulted due to asymmetric occupation of electrons in the d-orbitals. The $\mathrm{Cu}^{2+}$ ion in square pyramidal complexes possesses two electrons in the $\mathrm{d}_{z}{ }^{2}$ orbitals, whereas the $\mathrm{d}_{x^{2}-y^{2}}$ orbital accommodates only 

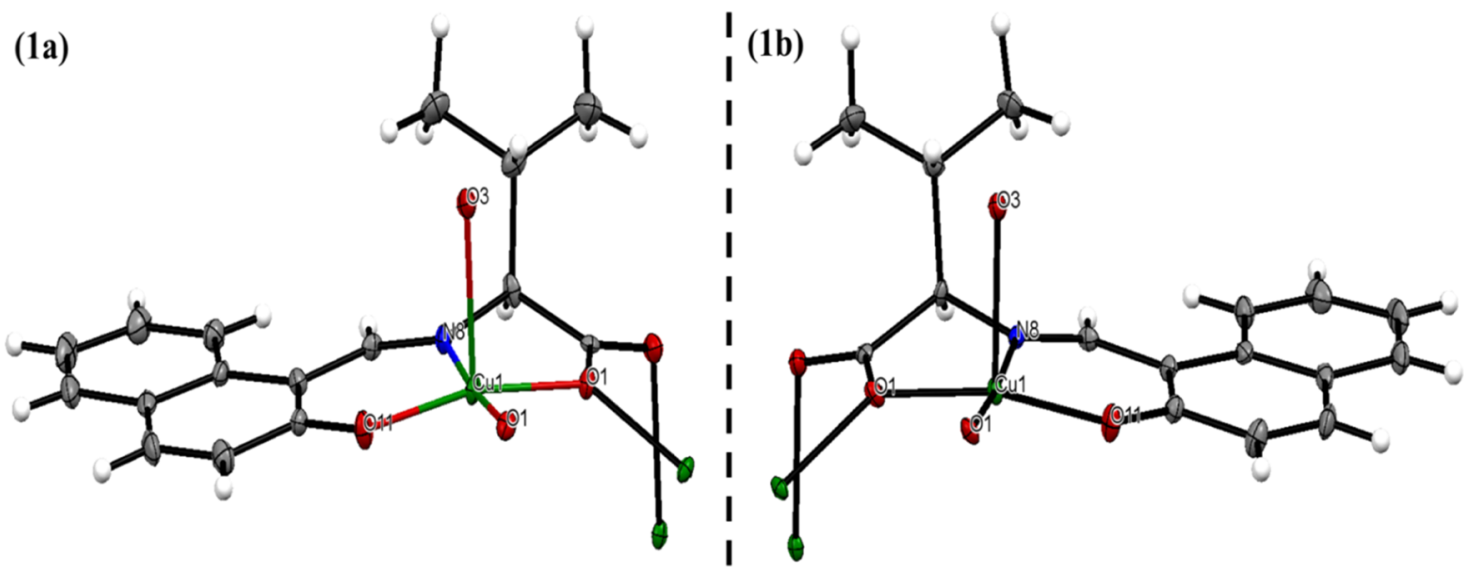

Figure 2. Crystal structure of enantiomeric Schiff base $\mathrm{Cu}(\mathrm{II})$ complexes $\mathbf{1 a}$ and $\mathbf{1 b}$ across the mirror plane.
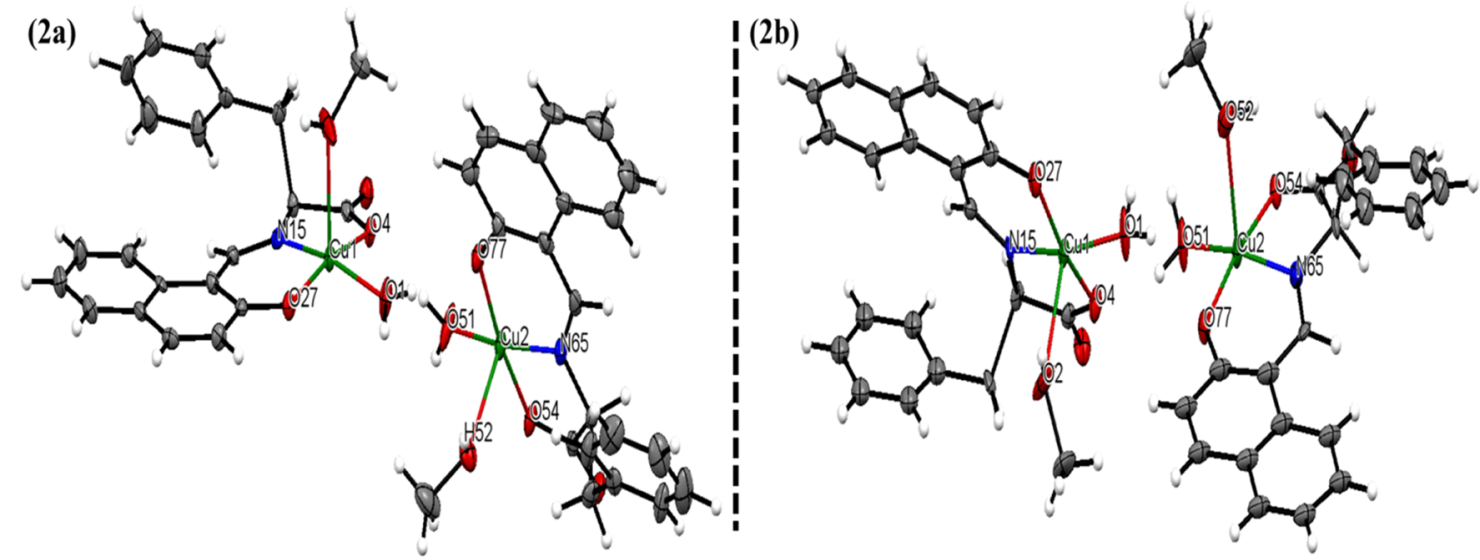

Figure 3. Crystal structure of enantiomeric Schiff base $\mathrm{Cu}(\mathrm{II})$ complexes $\mathbf{2} \mathbf{a}$ and $\mathbf{2} \mathbf{b}$ as twin molecules across the mirror plane.

one electron. The deviation from planarity of the equatorial plane was also observed in the trans angles $\{\mathrm{O}(1)-\mathrm{Cu}(1)-$ $\mathrm{O}(11), \mathrm{N}(8)-\mathrm{Cu}(1)-\mathrm{O}(1)\}$, which were 164.46 and $173.84^{\circ}$. The trigonality index $\tau$ is calculated by analyzing $\alpha$ and $\beta$ (the largest angles around the $\mathrm{Cu}$ (II) ion), and it was found to be 0.156 and 0.158 for complexes $\mathbf{1 a}$ and $\mathbf{1 b}$, respectively. Since the observed $\tau=0$ and 1 have been assigned to perfectly square pyramidal and trigonal bipyramidal geometries, the geometry around the $\mathrm{Cu}$ (II) center in complexes $\mathbf{1 a}$ and $\mathbf{1 b}$ could be described as distorted square pyramidal. ${ }^{42}$ The crystal structure involves significant carbon-carbon interactions between the imine $(-\mathrm{HC}=\mathrm{N})$ carbon and the carbon atom of the planar aromatic system of the parallely arranged Schiff base moieties. Intermolecular hydrogen bonding has also been observed within the structural framework involving imine nitrogen and the metal-bound oxygen atom, generating a onedimensional polymeric array of the crystal along the " $c$ "-axis (Figure S3). The distance between the two $\mathrm{Cu}$ (II) centers was found to be $3.585 \AA$.

Complexes $\mathbf{2 a}$ and $\mathbf{2 b}$ crystallize as twin molecules in the orthorhombic crystal system with the $P 2_{1} 2_{1} 2_{1}$ space group. The $\mathrm{Cu}$ (II) metal ion in complex $\mathbf{2 a}$ exhibited distorted square pyramidal geometry with the $\mathrm{CuNO}_{4}$ chromophore having -ONO coordination from the Schiff base ligand and two oxygen donor atoms, one from the coordinated water molecule and another from the solvent molecule, that is, methanol (Figure 3). Complex $\mathbf{2 b}$ showed a similar coordination environment around the $\mathrm{Cu}(\mathrm{II})$ center, except that the $\mathrm{C} 7$ and C57 carbon atoms have $R$-configuration, whereas $S$ configuration was found in complex $2 \mathrm{a}$. The $\mathrm{NO}_{4}$ coordination sphere in complex $\mathbf{2 a}$ was slightly deviated from the square pyramidal geometry having trigonality index $\tau$ values of 0.0203 and 0.0355 for $\mathrm{Cu}(1)$ and $\mathrm{Cu}(2)$, respectively. Similarly for complex $\mathbf{2 b}$, the trigonality index $\tau$ values of 0.0416 and 0.0433 for $\mathrm{Cu}(1)$ and $\mathrm{Cu}(2)$, respectively, revealed a distorted square pyramidal geometry along the two $\mathrm{Cu}(\mathrm{II})$ centers. The deviation from planarity in the equatorial plane was also observed through trans angles $\{\mathrm{O}(27)-\mathrm{Cu}(1)-\mathrm{O}(4), \mathrm{N}(15)-$ $\mathrm{Cu}(1)-\mathrm{O}(1)\}$, which were found to be 168.41 and $165.99^{\circ}$ for $\mathrm{Cu}(1)$, and $\{\mathrm{O}(77)-\mathrm{Cu}(1)-\mathrm{O}(54), \mathrm{N}(65)-\mathrm{Cu}(1)-\mathrm{O}(51)\}$, which were found to be 168.35 and $167.07^{\circ}$ for $\mathrm{Cu}(2)$ in complex 2 a. The axial site in $\mathbf{2 a}$ was occupied by an oxygen atom with an average $\mathrm{Cu}(1)-\mathrm{O}$ distance of $(2.26 \AA)$ and $\mathrm{Cu}(2)-\mathrm{O}$ distance of $2.31 \AA$, whereas the basal plane consisted of an oxygen atom from a coordinated water molecule with $\mathrm{Cu}(1)-\mathrm{O}$ and $\mathrm{Cu}(2)-\mathrm{O}$ bond distances of (1.957 $\AA$ ) and $(1.96 \AA)$, respectively. Thus, longer $\mathrm{Cu}-\mathrm{O}$ bond distances were observed for axial oxygen atoms as compared with those occupying the basal position, revealing distortion in the geometry around the metal center as previously reported for other copper complexes. ${ }^{43}$ The crystal structure involves significant intermolecular $\mathrm{C}-\mathrm{C}$ interaction between the $\mathrm{C} 26$ carbon atom of hydroxy naphthaldehyde and the $\mathrm{C} 5$ carbon atom belonging to the carboxylate group (Figure S4). 
(1a)

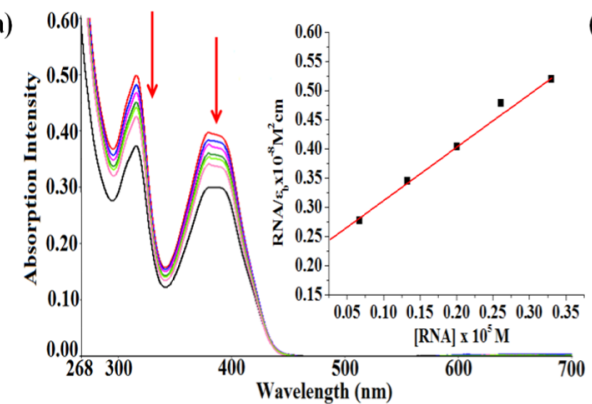

(2a)

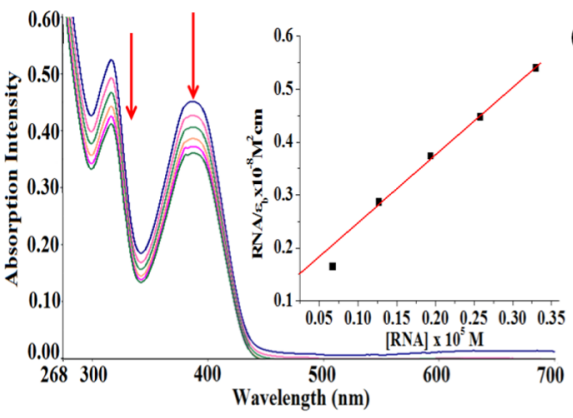

(1b)

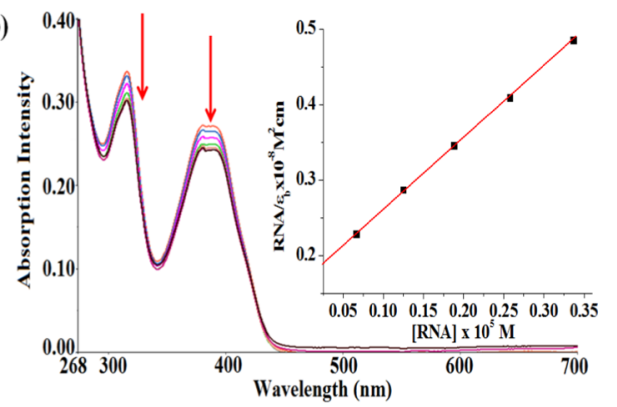

(2b)

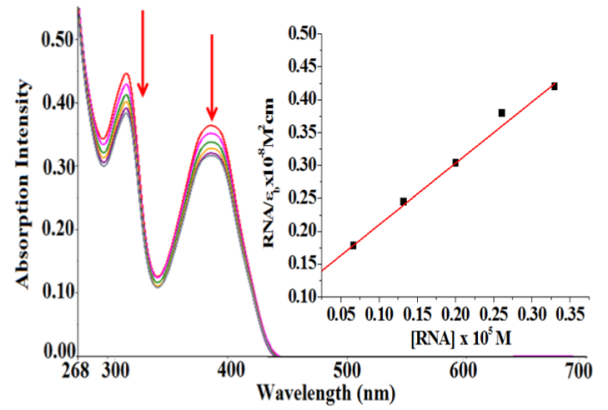

Figure 4. Absorption spectra of complexes 1 and 2 ( $\mathbf{a}$ and $\mathbf{b})$ in the presence of increasing tRNA concentration $\left((0-0.5) \times 10^{-5} \mathrm{M}\right)$.

Table 1. Binding Constant Values for Complexes 1 and 2 (a and b)

\begin{tabular}{|c|c|c|c|c|c|c|c|c|}
\hline \multirow[b]{2}{*}{ complexes } & \multicolumn{2}{|c|}{$K_{\mathrm{b}}$ values $\left(\mathrm{M}^{-1}\right)$} & \multicolumn{2}{|c|}{$\%$ hypochromism } & \multicolumn{2}{|c|}{$\Delta G\left(\mathrm{~kJ} \mathrm{~mol}{ }^{-1}\right)$} & \multicolumn{2}{|c|}{$K_{\text {sv }}$ values } \\
\hline & ct-DNA & tRNA & ct-DNA & tRNA & ct-DNA & tRNA & ct-DNA & tRNA \\
\hline 1a & $6.66( \pm 0.05) \times 10^{5}$ & $7.55( \pm 0.04) \times 10^{5}$ & 29 & 25 & -33.19 & -33.52 & 1.12 & 2.10 \\
\hline $1 b$ & $6.54( \pm 0.08) \times 10^{5}$ & $7.25( \pm 0.06) \times 10^{5}$ & 27 & 24 & -33.17 & -33.42 & 1.06 & 2.04 \\
\hline $2 a$ & $7.65( \pm 0.03) \times 10^{5}$ & $8.55( \pm 0.04) \times 10^{5}$ & 32 & 35 & -33.54 & -33.81 & 1.25 & 2.29 \\
\hline $2 b$ & $7.45( \pm 0.04) \times 10^{5}$ & $8.45( \pm 0.02) \times 10^{5}$ & 30 & 33 & -33.49 & -33.79 & 1.16 & 2.14 \\
\hline
\end{tabular}

Hirshfield Surface Analysis. Hirshfield surface analysis of the L-enantiomeric $\mathrm{Cu}$ (II) complexes $\mathbf{1 a}$ and $\mathbf{2 a}$ were carried out to describe their surface characteristics and also to analyze the nature and extent of various intermolecular interactions qualitatively within the crystal structure ${ }^{44}$ (Figure S5).

The $d_{\text {norm }}$ surface characterizes various close intermolecular interactions in which the red region corresponds to closer intermolecular contacts, whereas the blue region represents larger intermolecular contacts than the van der Waals radii. The deep-red regions observed on the dnorm surfaces of complexes $\mathbf{1 a}$ and $\mathbf{2 a}$ are indicative of the close interactions, mainly responsible for $\mathrm{H} \cdots \mathrm{H}$ and $\mathrm{C} \cdots \mathrm{H}$ bonding in the complexes. The red regions displayed on the shape index function show $\mathrm{C}-\mathrm{H} \cdots \pi$ interactions and bow-tie patterns, indicating the presence of aromatic stacking. The curved surface for the complexes revealed the presence of electron density around the intermolecular interactions.

The two-dimensional (2D) fingerprint plots of complexes 1a and $\mathbf{2 a}$ are shown in Figure S6, which project various intermolecular contacts between the atoms. The most significant interaction found in the complexes is $\mathrm{H} \cdots \mathrm{H}$ contact, which is shown in the middle of the scattered plot as a lightblue region and contribute to 44.5 and $50.2 \%$ of the total interactions in $\mathbf{1 a}$ and $\mathbf{2 a}$, respectively. The other important interactions that stabilize the crystal structure are $\mathrm{C} \cdots \mathrm{H}$ interactions, whose contributions were found to be 15.2 and $14.4 \%$ in $\mathbf{1 a}$ and $2 \mathrm{a}$, respectively, and $\mathrm{H} \cdots \mathrm{C}$ interactions, which contribute to $12 \%$ in both the complexes. Apart from these, other short interactions were also observed, viz., $\mathrm{O} \cdots \mathrm{O}, \mathrm{O} \cdots \mathrm{C}$, and $\mathrm{O} \cdots \mathrm{H}$ interactions, which correspond to the large red regions observed on the $d_{\text {norm }}$ surfaces of the complexes and are summarized in Table S6.

Interaction Studies with Nucleic Acids (DNA and RNA). Absorption titrations of complexes $\mathbf{1}$ and $\mathbf{2}$ (a and b) with ct-DNA and tRNA were performed by monitoring the perturbation in the electronic spectra upon increasing the nucleic acid concentration to determine the mode of binding intercalative vs electrostatic surface interaction and affinity. The absorption plots of $\mathbf{1}$ and $\mathbf{2}$ ( $\mathbf{a}$ and $\mathbf{b}$ ) reveal "hypochromism" at the absorbance maxima for the intraligand band centered at $316 \mathrm{~nm}$ and charge transfer bands at $381 \mathrm{~nm}$ in the case of ct-DNA and tRNA (Figures S7 and 4), respectively. Hypochromism with red or no shift is associated with the intercalative mode of interaction with the nucleic acids, viz., ct-DNA and tRNA, due to strong stacking interactions between the electronic states of the intercalating chromophore and the nucleobases. ${ }^{45}$

These results revealed that complexes $\mathbf{1}$ and $\mathbf{2}$ ( $\mathbf{a}$ and $\mathbf{b}$ ) bind to the ct-DNA and tRNA biomolecules via the intercalative mode. The corresponding binding constant $K_{b}$ was calculated using the Wolfe-Shimer (eq 1) and Gibb's free energy values from eq 2 for complexes $\mathbf{1}$ and $\mathbf{2}$ ( $\mathbf{a}$ and $\mathbf{b}$ ) with ct-DNA and tRNA and are tabulated in Table 1.

$$
\begin{aligned}
& \text { [DNA or RNA }] /\left(\varepsilon_{\mathrm{a}}-\varepsilon_{\mathrm{f}}\right) \\
& \quad=[\mathrm{DNA} \text { or RNA }] /\left(\varepsilon_{\mathrm{b}}-\varepsilon_{\mathrm{f}}\right)+1 / K_{\mathrm{b}}\left(\varepsilon_{\mathrm{b}}-\varepsilon_{\mathrm{f}}\right)
\end{aligned}
$$




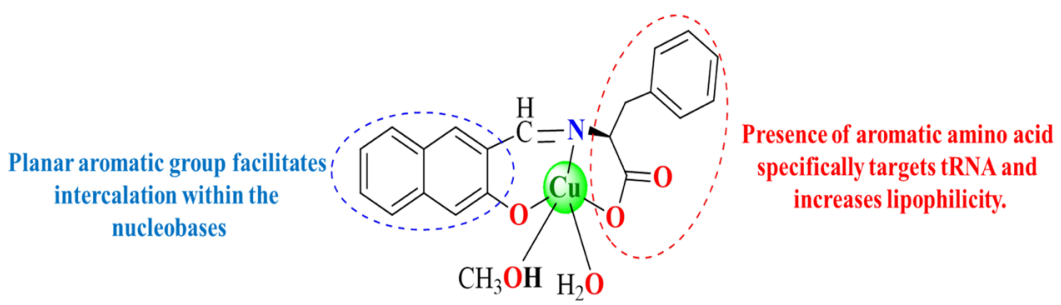

Figure 5. Various recognition domains present in the copper complexes targeted to tRNA.

where [DNA or RNA] is the ct-DNA/tRNA concentration, and $\varepsilon_{\mathrm{a}}, \varepsilon_{\mathrm{f}}$, and $\varepsilon_{\mathrm{b}}$ DNA/tRNA are the apparent $\left(A_{\mathrm{abs}} /[\mathrm{Cu}(\mathrm{II})\right.$ complex]), free, and bound complex extinction coefficients, respectively.

In a plot of $[\mathrm{DNA} / \mathrm{RNA}] /\left(\varepsilon_{\mathrm{a}}-\varepsilon_{\mathrm{f}}\right)$ vs $[\mathrm{DNA} / \mathrm{RNA}]$ with a slope of $1 /\left(\varepsilon_{\mathrm{b}}-\varepsilon_{\mathrm{f}}\right)$ and an intercept of $1 / K_{\mathrm{b}}\left(\varepsilon_{\mathrm{b}}-\varepsilon_{\mathrm{f}}\right)$, the $K_{\mathrm{b}}$ values were obtained by the ratio of the slope to the intercept.

$$
\Delta G=-R T \ln K_{\mathrm{b}}\left[\text { where } R=8.314 \mathrm{JK}^{-1} \mathrm{~mol}^{-1} ; T=298 \mathrm{~K}\right]
$$

where $\Delta G$ is the change in Gibb's free energy, $R$ is the gas constant, $T$ is temperature, and $K_{\mathrm{b}}$ is the binding constant.

To further support the binding mode of the complexes and to explore the binding site and selectivity, a fluorescence intercalator displacement (FID) assay was performed for complexes $\mathbf{1}$ and $\mathbf{2}$ (a and $\mathbf{b}$ ), which employs the displacement of the intercalator molecule, ethidium bromide, exhibiting strong fluorescence around $590 \mathrm{~nm}\left(\lambda_{\mathrm{ex}}=510 \mathrm{~nm}\right)$ upon interaction with the ct-DNA/tRNA biomolecule. On addition of complexes $\mathbf{1}$ and $\mathbf{2}$ ( $\mathbf{a}$ and $\mathbf{b}$ ), a decrease in fluorescence intensity was observed due to replacement of the bound intercalator, where the percent decrease in fluorescence is directly related to the extent of binding. Fluorescence titration spectra with increasing concentration of complexes $\mathbf{1}$ and $\mathbf{2}$ (a and b) $\left(1 \times 10^{-4} \mathrm{M}\right)$ depicted that the fluorescence of the ctDNA/tRNA-EB system was quenched due to the interaction of the complexes with the base pairs displacing the probe from the DNA/RNA-EB system ${ }^{46}$ (Figures S8 and S9).

The quenching constant $K_{\mathrm{sv}}$ values for complexes 1 and 2 (a and $\mathbf{b}$ ) were obtained by employing the Stern-Volmer equation

$$
I_{\mathrm{o}} / I=1+K_{\mathrm{sv}}[\mathrm{Q}]
$$

where $I_{\mathrm{o}}$ and $I$ are the fluorescence intensities in the absence and presence of the test compound, respectively, $K_{\mathrm{sv}}$ is the quenching constant, and $[\mathrm{Q}]$ is the quencher concentration. The $K_{\text {sv }}$ values for complexes $\mathbf{1}$ and $\mathbf{2}(\mathbf{a}$ and $\mathbf{b}$ ) are depicted in Table 1.

As shown in Table 1 , the $K_{\mathrm{b}}$ and $K_{\mathrm{sv}}$ values of $\mathrm{L}$-enantiomeric complexes are higher in magnitude than D-enantiomeric complexes, with complex $\mathbf{2 a}$ possessing the highest binding propensity. Though these changes are subtle, nevertheless, we can ascertain the sensitivity of enantiomers toward the target molecules. These results indicated selective disposition of the L-enantiomeric complexes toward the biomolecular target, which could be attributed to the effect of the chiral stereogenic center and increased lipophilicity due to the presence of the phenylalanine moiety in complex 2a. Furthermore, the complexes 2 (a and $\mathbf{b}$ ) showed significantly higher binding propensity toward the tRNA as compared to ct-DNA, which could be rationalized as structural novelty of Schiff base amino acid copper(II) complexes possessing recognition elements (i)
$\mathrm{CH}=\mathrm{N}$ imine linkage with planar aromatic naphthaldehyde moiety facilitating intercalation within the nucleobases and (ii) amino acid ligands to specifically target the tRNA biomolecule (Figure 5).

Circular dichroism (CD) spectroscopy is considered to be an efficient technique for both stereochemical analysis and to study the conformational variations in the chiral biopolymers upon interaction with the complexes. The $\mathrm{CD}$ spectrum of the characteristic right-hand B-form DNA consists of a positive band at $275 \mathrm{~nm}$ due to base stacking and a negative band at $245 \mathrm{~nm}$ due to right-handed helicity. Interaction of complexes with ct-DNA through the groove binding or electrostatic mode exhibits less or no perturbation, whereas intercalation results in the enhancement of these optical signatures. The CD spectra of complexes $\mathbf{1}$ and $\mathbf{2}$ ( $\mathbf{a}$ and $\mathbf{b}$ ) in the presence of ct-DNA (Figure S10) revealed that the complexes increase the ellipticity of the bands with a wavelength shift, indicating intercalation of these complexes within the nucleobases of the DNA helix as a dominant mode of interaction.

The CD spectrum of the tRNA molecule displayed two positive peaks at 221 and $270 \mathrm{~nm}$ and two negative peaks at 208 and $240 \mathrm{~nm}$ (Figure 6). Upon addition of complexes 1 and

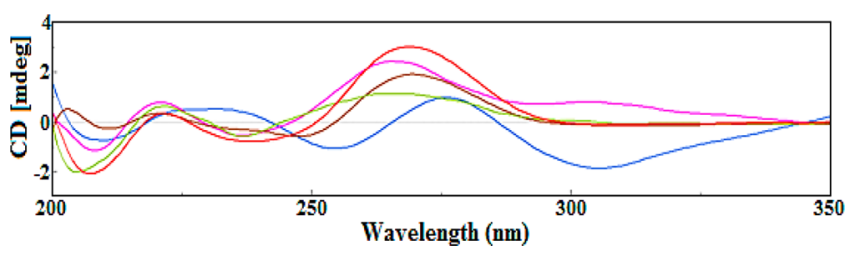

Figure 6. CD spectra of tRNA alone (red) and in the presence of complexes 1a (green), $\mathbf{1 b}$ (pink), 2a (blue), and $\mathbf{2 b}$ (brown).

2 ( $\mathbf{a}$ and $\mathbf{b}$ ), a decrease in the ellipticity of the positive band at $270 \mathrm{~nm}$ and an increase in the ellipticity of the other bands centered at 208, 221, and $240 \mathrm{~nm}$ with a wavelength shift were observed, which implicated the intercalative mode of binding of the complexes with tRNA. The shift in the wavelength of the $\mathrm{CD}$ bands indicates that the tRNA molecule undergoes conformational changes. Similar spectral changes in CD have also been reported previously for the $\mathrm{Cu}$ (II) complexes containing planar ligand moieties. ${ }^{47}$ It is evident from the CD spectra that complexes $\mathbf{1}$ and $\mathbf{2}$ ( $\mathbf{a}$ and $\mathbf{b}$ ) interact enantioselectively with both the tRNA and ct-DNA, and further, the complexes exhibit significantly higher binding affinity toward tRNA than ct-DNA molecule.

Hydrodynamic measurements were carried out to investigate the binding interactions between chiral metal complexes and ct-DNA by varying the concentration of metal complexes 1 and $\mathbf{2}$ (a and $\mathbf{b}$ ). The intercalation model reveals that the base pairs get widened as the intercalator molecule acts as a "wedge" between base pairs upon binding, lengthening the DNA helix and thereby increasing the viscosity. However, in the case of 

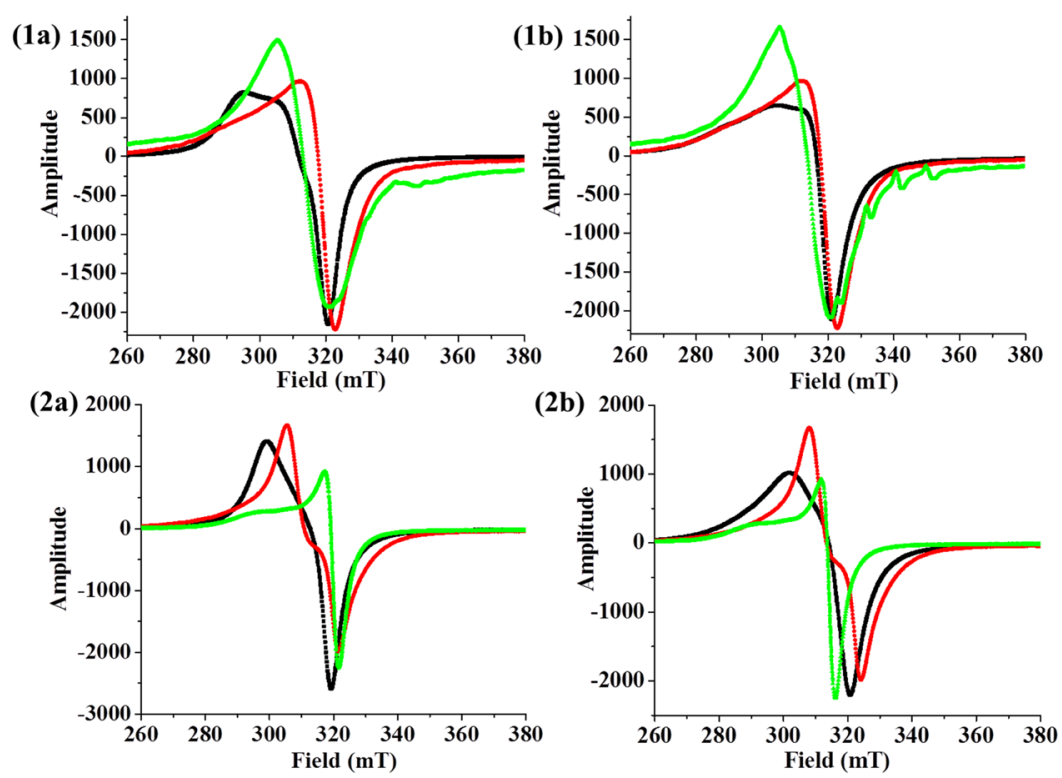

Figure 7. EPR spectra of complexes $\mathbf{1}$ and $\mathbf{2}$ (a and $\mathbf{b}$ ) (black) showing variation in the signal amplitude when binding to ct-DNA (red) and tRNA (green).

(a)

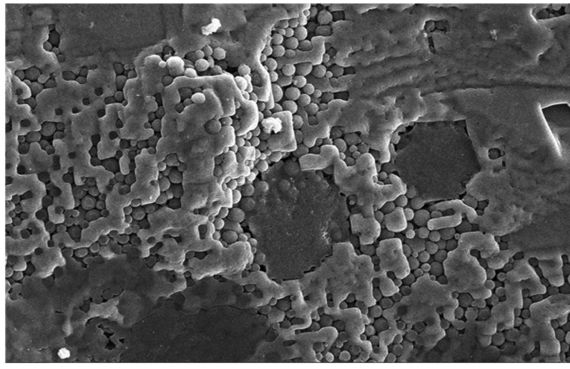

(c)

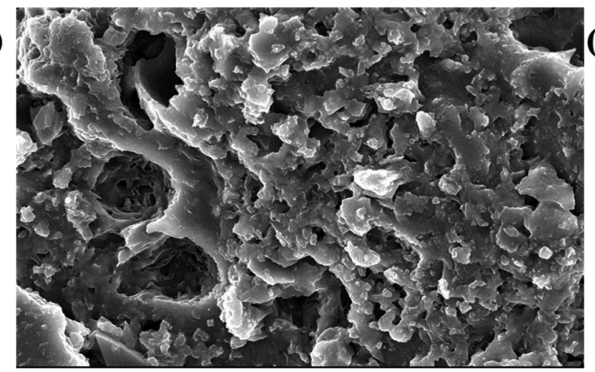

(b)

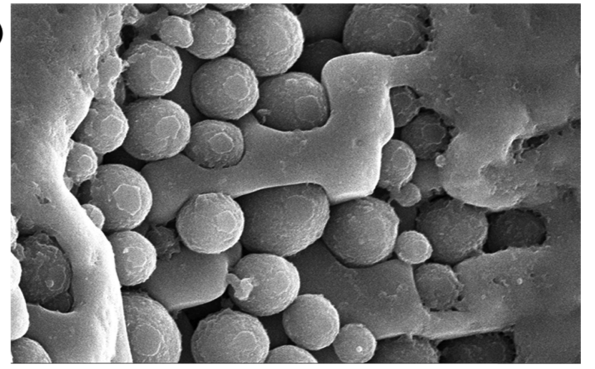

(d)

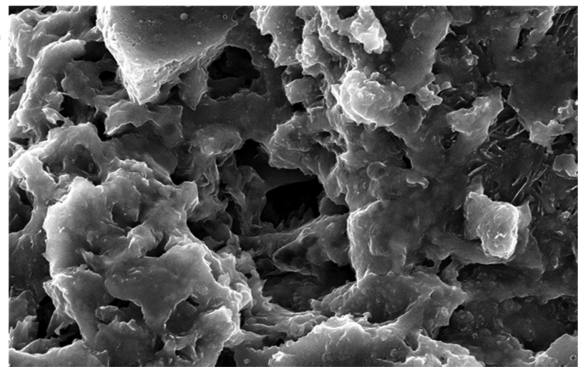

Figure 8. SEM images of complex 1a showing surface morphology upon condensation with ct-DNA (a, b) and tRNA (c, d).

nonclassical intercalation or groove binding, interaction of the ligand molecule induces bend or kink in the DNA helix, reducing its effective length, complemented by a decrease in relative viscosity. The effect of increasing concentrations of complexes $\mathbf{1}$ and $\mathbf{2}$ ( $\mathbf{a}$ and $\mathbf{b}$ ) on viscosity was examined in the presence of ct-DNA (Figure S11). It was observed that on increasing the concentration of complexes $\mathbf{1}$ and $\mathbf{2}$ ( $\mathbf{a}$ and $\mathbf{b}$ ), the relative viscosity increased steadily, which showed that the complexes bind to the DNA molecule through intercalation. ${ }^{48}$ However, viscosity measurements could not be employed to study the interaction of complexes with tRNA as it does not possess a linear structure. ${ }^{49}$

The intercalating mode of binding by these Schiff base complexes was also determined by thermal denaturation studies. To investigate the effects of complexes $\mathbf{1}$ and $\mathbf{2}$ (a and $\mathbf{b})$ on the thermal stability of ct-DNA, melting temperature was determined from the thermal denaturation plots for DNA (Figure S12). It was observed that the addition of complexes $\mathbf{1}$ and $\mathbf{2}$ ( $\mathbf{a}$ and $\mathbf{b}$ ) (at a fixed concentration of 0.2 $\mu \mathrm{M})$ induced a significant increase in the melting temperatures $\left(\Delta T_{\mathrm{m}}\right)$ in the range of $6-8{ }^{\circ} \mathrm{C}$, indicating stabilization of the DNA double helix, suggesting intercalation of the planar aromatic ring system between the nucleobases of DNA. ${ }^{50}$ The $\Delta T_{\mathrm{m}}$ values for the L-enantiomeric complexes 1a and 2a were more than the values observed for the corresponding $\mathrm{D}$ enantiomeric complexes $\mathbf{1 b}$ and $\mathbf{2 b}$, respectively. Since the RNA molecule possesses a unispiral structure, thermal denaturation experiments cannot be performed with tRNA. ${ }^{51}$

Electron paramagnetic resonance (EPR) binding studies were performed ( $\mathrm{pH}=7.0$ ) with ct-DNA/tRNA for complexes $\mathbf{1}$ and $\mathbf{2}$ ( $\mathbf{a}$ and $\mathbf{b}$ ) to identify the potential binding modes upon interaction with the biomolecules, which alters the EPR parameters. Interaction of the nucleic acids causes diminution/ increase in the EPR signal intensity, which is quantified as the 
(a)

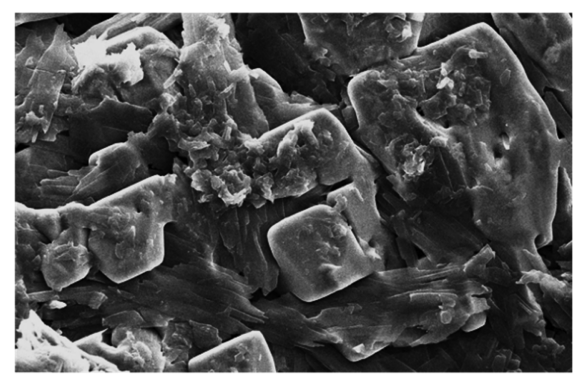

(c)

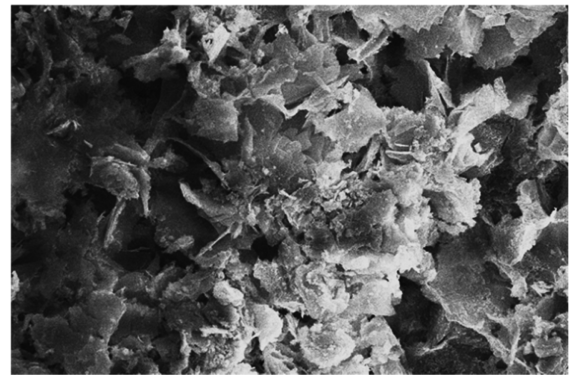

(b)

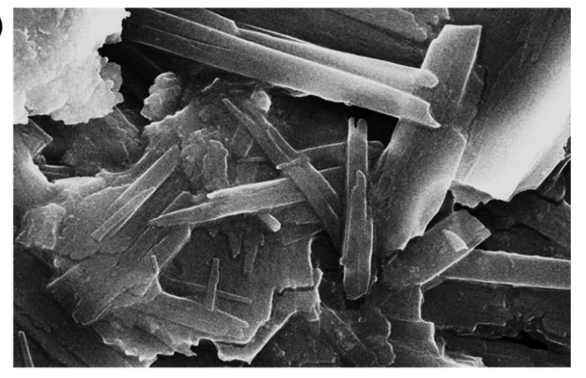

(d)

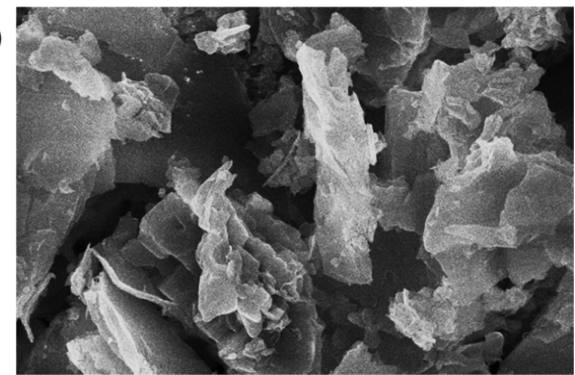

Figure 9. SEM images of complex 2a showing surface morphology upon condensation with ct-DNA (a, b) and tRNA (c, d).

amount of metal complex interacting with the biomolecule. As shown in Figure 7, the EPR spectra of complexes 1 and 2 (a and b) after interaction with ct-DNA/tRNA revealed shifting of the EPR spectral signatures, indicating that the $\mathrm{Cu}(\mathrm{II})$ coordination sphere was deformed upon interaction with the DNA/RNA biomolecule. These spectral behaviors suggested that one oxygen atom at the axial position from the pentacoordinated $\mathrm{Cu}(\mathrm{II})$ environment is replaced by a nitrogen atom from DNA/RNA nucleobases. ${ }^{52}$ However, a significant shift was observed for complexes in the presence of the tRNA molecule, implying stronger binding affinity of these complexes toward RNA as depicted by other spectroscopic studies. Furthermore, chirality of the amino acid ligand is an important factor that influences its specific binding toward DNA/RNA, suggesting the stereochemical dependence of the complex toward ct-DNA/tRNA biomolecules. ${ }^{53-55}$ The changes in the spectral parameters of complexes $\mathbf{1}$ and 2 (a and b) alone and obtained after interaction with ct-DNA and tRNA are shown in Table S7.

Morphological Studies. DNA is a strongly charged hetero-biopolymer responsible for storage and processing of genetic information. Many small molecules such as multivalent cations, peptides, dendrimers, cationic polymers, and various intercalating agents can recognize and modify DNA in vivo in the condensed state. In medicinal chemistry, various generegulated processes and controlled drug delivery are governed by the DNA condensation phenomenon. The condensation phenomenon is also associated with the activity of various anticancer drugs. ${ }^{56}$ Transition metals are highly charged species that can induce DNA condensation in vitro and in vivo and change the morphology of DNA/RNA like toroids, rodlike shapes, charged globules, segregated chains, and bundles depending upon solution conditions (ionic strength and polarity). ${ }^{57}$ Since the sugar phosphate backbone of the DNA/RNA helices is negatively charged and has surface minor and major grooves, substrates with positive charge or containing aromatic ligands can be intercalated in between the nucleobases of the DNA/RNA, which may result in the condensation process.
The scanning electron microscopy (SEM) studies reveal that the DNA molecules upon condensation with complex 1a revealed the formation of globular structures (Figure 8), which indicates the presence of a charged surface resulting due to repulsion between positively charged amino groups present in the complex. ${ }^{58}$ On the other hand, complex $2 \mathrm{a}$ showed the presence of rodlike structures (Figure 9) probably resulting due to electrostatic repulsion between the uncompensated charges of the DNA helix. ${ }^{59}$ However, the micrographs for complexes 1a and $\mathbf{2 a}$ with the tRNA molecule demonstrate the formation of crystalline surface morphologies. Magnified view of the micrographs shows the formation of concretelike structures containing hollow tubes indicative of tRNA condensation into compact massive structures. These morphological changes can be attributed to the charge neutralization due to electrostatic interaction between the negatively charged phosphate groups of the RNA and the positively charged groups of the cations. ${ }^{60}$

DNA Cleavage Studies. Agarose gel electrophoresis is a versatile technique for monitoring DNA cleavage activity induced in the presence of complexes by observing the changes in DNA mobility on applying an electric field. In general, when plasmid DNA is subjected to electrophoresis, the fastest migration results in the conversion of a supercoiled form (form I) to a relaxed nicked form (form II) implicating single-strand DNA scission. However, the appearance of the linearized form of DNA (form III) between form I and form II suggests that both the strands of DNA are cleaved. Concentrationdependent cleavage experiments of L-enantiomeric $\mathrm{Cu}$ (II) complexes 1a and 2a with the pBR322 plasmid DNA were carried out by the gel electrophoresis method. The electrophoretic bands (Figure S13) showed conversion of the supercoiled (form I) to nicked form (form II) on increasing the concentration of complexes $\mathbf{1 a}$ and $\mathbf{2} \mathbf{a}$ with the appearance of a linear form (form III) suggestive of lethal double-strand scission induced by the complexes. Furthermore, complex $\mathbf{2 a}$ demonstrated much efficient cleavage at low micromolar concentration $(40 \mu \mathrm{M})$ as compared to $1 \mathrm{a}(50 \mu \mathrm{M})$, which could be attributed to the differential DNA binding behavior 
due to structural modulation in the presence of the aromatic phenyl group in complex $\mathbf{2 a}$.

The potential of copper complexes $1 \mathbf{a}$ and $2 \mathrm{a}$ to cleave the plasmid DNA in the presence of an activator, viz., $\mathrm{H}_{2} \mathrm{O}_{2}$, was also studied (Figure 10, lane 3). It was observed that both the

(a)

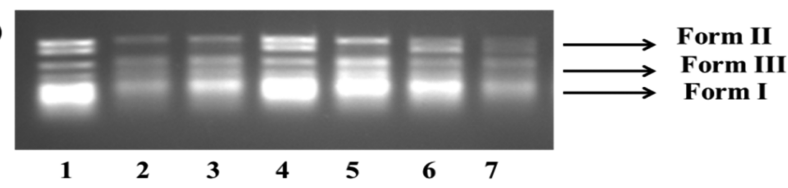

(b)

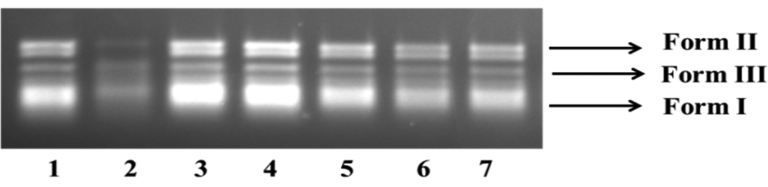

Figure 10. Agarose gel electrophoresis showing the cleavage of pBR322 supercoiled DNA (300 ng) by complexes 1a $(50 \mu \mathrm{M})$ and $\mathbf{2 a}$ $(40 \mu \mathrm{M})$ at $37{ }^{\circ} \mathrm{C}$ after $45 \mathrm{~min}$ of incubation in the presence of different ROS and groove binding agents. (a) lane 1, DNA control; lane 2, 1a + DNA; lane 3, 1a $+\mathrm{H}_{2} \mathrm{O}_{2}(0.4 \mu \mathrm{M})+$ DNA; lane 4, 1a + sodium azide $(0.4 \mu \mathrm{M})+$ DNA; lane 5, 1a + SOD $(0.25 \mu \mathrm{M})+$ DNA; lane 6, 1a + ethyl alcohol $(0.4 \mu \mathrm{M})+$ DNA; lane $7,1 \mathrm{a}+\mathrm{DNA}+$ methyl green $(0.16 \mu \mathrm{M})$; (b) lane 1, DNA control; lane 2, 2a + DNA; lane 3, 2a $+\mathrm{H}_{2} \mathrm{O}_{2}(0.4 \mu \mathrm{M})+$ DNA; lane $4,2 \mathrm{a}+$ sodium azide $(0.4$ $\mu \mathrm{M})+$ DNA; lane 5, 2a + SOD $(0.25 \mu \mathrm{M})+$ DNA; lane 6, 2a + ethyl alcohol $(0.4 \mu \mathrm{M})+\mathrm{DNA}$; lane $7,2 \mathrm{a}+\mathrm{DNA}+$ methyl green $(0.16$ $\mu \mathrm{M})$

complexes are capable of cleaving the supercoiled plasmid DNA in the presence of $\mathrm{H}_{2} \mathrm{O}_{2}$, which suggested that the complexes follow an oxidative pathway. The mechanistic investigations of cleavage reactions of complexes $1 \mathrm{a}$ and $\mathbf{2 a}$ in the presence of reactive oxygen species (ROS) such as singlet oxygen quencher $\left(\mathrm{NaN}_{3}\right)$, superoxide oxygen scavenger (SOD), and hydroxyl radical scavenger $(\mathrm{EtOH})$ were carried out to validate the oxidative vs hydrolytic cleavage pathway. Copper complexes have proven to cleave DNA by reacting with molecular oxygen or hydrogen peroxide to generate various active oxidative intermediates. Addition of $\mathrm{NaN}_{3}$ and SOD significantly reduced the cleavage activity of complexes (Figure 10, lanes 4 and 5), suggesting the involvement of singlet oxygen species $\left({ }^{1} \mathrm{O}_{2}\right)$ and superoxide anions $\left(\mathrm{O}_{2}{ }^{\bullet-}\right)$ in the cleavage phenomenon. The complexes also showed marked inhibition of the cleavage activity in the presence of EtOH (Figure 10, lane 6), indicating that diffusible $\left({ }^{\bullet} \mathrm{OH}\right)$ hydroxyl radicals could participate in the cleavage process. The findings of the above experiments affirm that the cleavage process induced in the presence of $\mathrm{Cu}$ (II) complexes was mediated via the oxidative pathway involving the formation of copper-oxo species. $^{61}$

To explore the groove binding preference of complexes, DNA was incubated with methyl green, which is a major groove binder of the DNA helix. The electrophoretic bands in the presence of complexes $1 \mathbf{a}$ and $\mathbf{2 a}$ revealed that addition of methyl green (Figure 10, lane 7) did not further inhibit DNA cleavage, suggesting minor groove preference of the complexes. These findings are very significant as previous literature reports reveal that the majority of the oxidative cleavage reagents bind preferentially through minor grooves rather than major grooves. $^{62}$

In summary, complexes $\mathbf{1 a}$ and $\mathbf{2} \mathbf{a}$ are found to be efficient oxidative cleaving agents capable of inducing double-strand scission of DNA. The reactive oxygen species (ROS) are found to play an important role in oxidative cleavage as they are responsible for DNA damage, which acts as a trigger for cell death in the presence of copper complexes. Here, the $\mathrm{Cu}$ (II) species are readily reduced to $\mathrm{Cu}(\mathrm{I})$ in the presence of a suitable redox agent $\mathrm{H}_{2} \mathrm{O}_{2}$, and the possible cleavage mechanism is mediated by a Fenton-type reaction (Figure 11).

RNA Cleavage Studies. The ability of metal ions incorporated in the ligand scaffold containing sequencerecognizing domains could promote cleavage of RNA phosphodiester bonds, which can be exploited for the development of newer, more efficacious chemotherapeutic drug candidates or artificial ribonucleases by selectively targeting the RNA molecule and inhibiting the gene expression. The single-stranded RNA can rapidly undergo cleavage as compared to the double-stranded helix of DNA because the phosphodiester bonds are chemically and enzymatically less stable in RNA than DNA. ${ }^{63}$

The RNA cleavage activity was carried out in the presence of increasing concentrations of complexes $\mathbf{1 a}$ and $\mathbf{2 a}$ in a timedependent manner after incubation periods of $3 \mathrm{~h}$ and $24 \mathrm{~h}$ at $37^{\circ} \mathrm{C}$, respectively. The gel electrophoresis results showed that after $3 \mathrm{~h}$ (Figure S14), the complexes exhibited a moderate effect on the RNA bands, demonstrating partial cleavage of the tRNA molecule. However, on increasing the concentration (from 6.25 to $15.25 \mu \mathrm{M}$ ), intensity of the bands was affected, inhibiting the RNA cleavage, which was more pronounced in the case of complex 2a. After an incubation of $24 \mathrm{~h}$, largely diminished bands were observed, which showed almost complete degradation (80-90\%) of the tRNA (Figure 12). Thus, it was concluded that the RNA cleavage ability of the complexes is both time and concentration dependent. ${ }^{64}$

Partition Coefficients $(\log P)$. Lipophilicity of a drug candidate provides insight into the inter- and intramolecular forces affecting the drug delivery across the bilipid membrane as well as its interaction with the target biomolecule. Thus, lipophilicity is an important factor in determining the pharmacokinetics and pharmacodynamics of a drug entity. The cytotoxic activity of the drug molecule is correlated with its lipophilicity and aqueous solubility-a higher lipophilicity facilitates better cellular uptake and enhanced activity against the tested cancer cell lines. ${ }^{65}$ The $\log P$ values for the ligands and their corresponding L-enantiomeric complexes 1a and $\mathbf{2 a}$

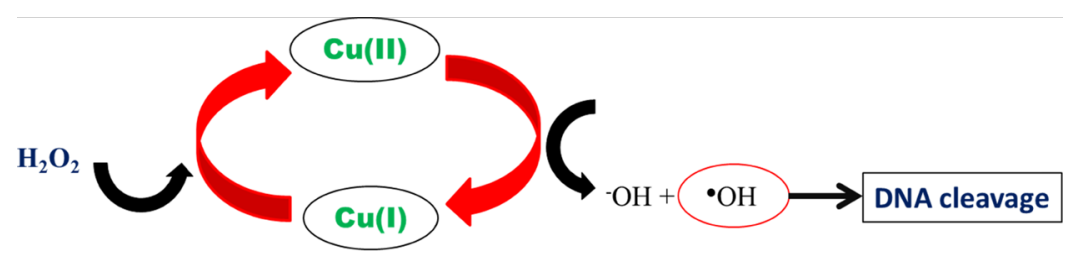

Figure 11. Proposed mechanism for oxidative DNA cleavage by $\mathrm{Cu}(\mathrm{II})$ complexes mediated via Fenton's pathway. 

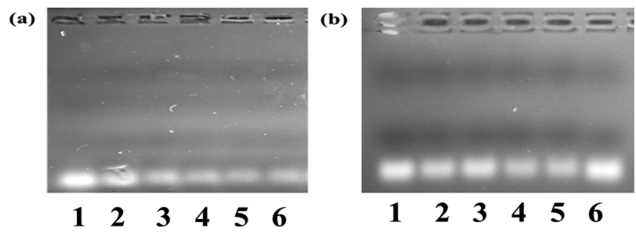

Figure 12. Agrose gel electrophoresis showing RNA cleavage after 24 $\mathrm{h}$ of incubation at $37{ }^{\circ} \mathrm{C}$ with increasing concentration of complexes 1a and 2a. (a) lane 1, tRNA control; lane 2, $6.25 \mu \mathrm{M}$ of 1a + tRNA; lane 3, $8.50 \mu \mathrm{M}$ of $1 \mathrm{a}+\mathrm{tRNA}$; lane $4,10.75 \mu \mathrm{M}$ of $1 \mathrm{a}+\mathrm{tRNA}$; lane 5, $13.00 \mu \mathrm{M}$ of $1 \mathrm{a}+$ tRNA; lane $6,15.25 \mu \mathrm{M}$ of $1 \mathrm{a}+\mathrm{tRNA}$; (b) lane 1, tRNA control; lane $2,6.25 \mu \mathrm{M}$ of $2 \mathrm{a}+\mathrm{tRNA}$; lane 3, $8.50 \mu \mathrm{M}$ of $2 \mathrm{a}$ + tRNA; lane $4,10.75 \mu \mathrm{M}$ of $2 \mathrm{a}+$ tRNA; lane $5,13.00 \mu \mathrm{M}$ of $2 \mathrm{a}+$ tRNA; lane $6,15.25 \mu \mathrm{M}$ of $2 \mathrm{a}+\mathrm{tRNA}$.

were calculated. For ligands $\mathbf{L} \mathbf{1}$ and $\mathbf{L} \mathbf{2}$, the $\log P$ values were found to be 1.77 and 2.45, which are lowered upon complexation with the $\mathrm{Cu}(\mathrm{II})$ ion to -1.61 and -1.29 , respectively (Table S6). The higher value of $\log P$ for ligand $\mathbf{L} 2$ and its complex 2a implicated higher lipophilicity validated by a stronger binding propensity of $2 \mathrm{a}$ toward ct-DNA/tRNA as well as higher cytotoxicity related to the structural modulation by introducing an aromatic amino acid ligand. ${ }^{66}$

Cytotoxic Activity. In vitro cytotoxicity of complexes 1 and $\mathbf{2}$ ( $\mathbf{a}$ and $\mathbf{b}$ ) was carried out by an SRB assay against three human cancer cell lines, viz., MCF-7, HeLa, and MIA-Pa-Ca-2 (Figure 13). The cytotoxicity profiles of the complexes demonstrate that the L-enantiomeric copper(II) complex 2a showed a significantly lower $\mathrm{GI}_{50}$ value $(<1 \mu \mathrm{M})$ as compared to its D-enantiomer bearing distinct selectivity toward the human breast cancer (MCF-7) cell line (Table S9).

The chelation of the copper(II) ion with the Schiff base scaffold containing the planar aromatic group of the phenylalanine moiety in complex 2a increases the lipophilicity, resulting in better cellular uptake and higher cytotoxic activity. However, poor activity was observed for the enantiomeric complexes $\mathbf{1 a}$ and $\mathbf{1 b}$, which could be attributed to their polymeric nature.

Molecular Modeling. To further elucidate the observed spectroscopic binding results of complexes $\mathbf{1}$ and $\mathbf{2}$ (a and $\mathbf{b}$ ), molecular modeling studies were carried out to explore the preferred binding sites and orientation of copper complexes within the DNA and RNA biomolecules. ${ }^{67}$ The complexes were docked with the DNA duplex of sequence d(CGCGAATTCGCG) ${ }_{2}$ dodecamer (PDB ID: 1BNA), and the resulting docked model revealed that the complexes could interact within the DNA double helix, preferentially in the minor groove GC region binding site. Complexes $\mathbf{1 a}$ and $\mathbf{1 b}$ showed preferred orientation in close proximity to C-23, G-22, C-21, A-5, G-4, A-6, C-3, and T-7 base pairs, whereas complexes $\mathbf{2 a}$ and $\mathbf{2} \mathbf{b}$ were found in close proximity to the nucleobases G-12, C-11, G-10, A-18, A-17, G-16, C-15, and G14 (Figures S15-S18). The binding energy values obtained for complexes 1 and 2 ( $\mathbf{a}$ and $\mathbf{b}$ ) were found to be -247.70 ,

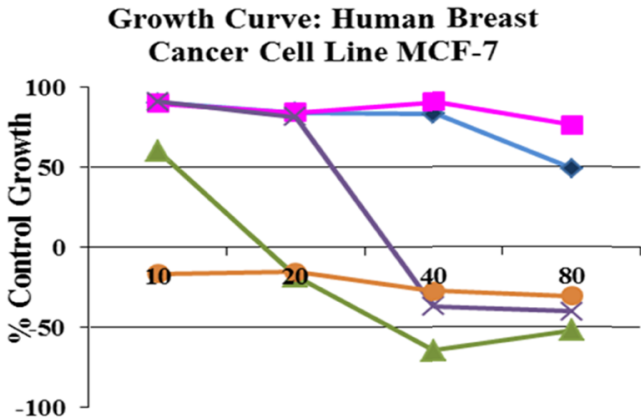

Drug Concentration $(\mu \mathrm{g} / \mathrm{ml})$

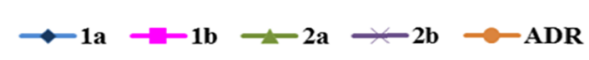

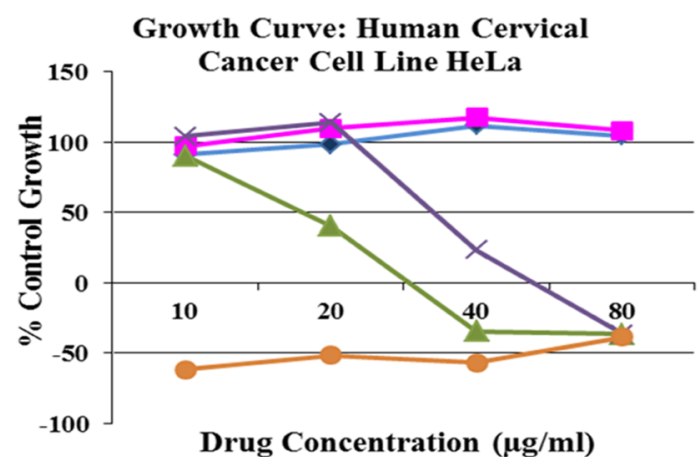

Drug Concentration $(\mu \mathrm{g} / \mathrm{ml})$

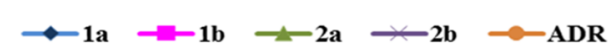

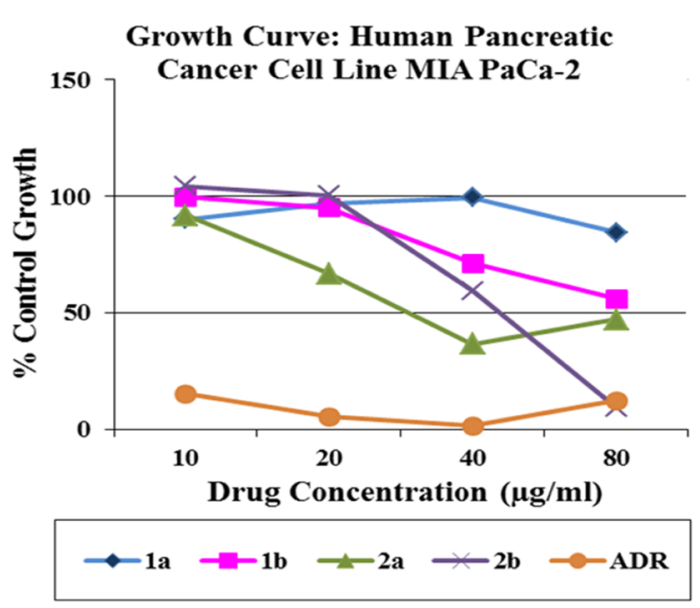

Figure 13. Growth curves of complexes 1 and 2 ( $\mathbf{a}$ and $\mathbf{b}$ ) evaluated against three different human cancer cell lines by the SRB assay. 
$-247.35,-262.69$, and $-262.25 \mathrm{KJ} \mathrm{mol}^{-1}$, which implicate higher binding energy for the L-enantiomeric $\mathrm{Cu}$ (II) complexes.

Docking experiments were also performed with tRNA (PDB ID: 6TNA) to further validate the binding results. The yeast tRNA consists of well-defined $3 \mathrm{D}$ regions including arms, a $\Psi$ loop, and anticodon regions. The docking results revealed that the complexes were inserted into the active pocket of the anticodon arm of the tRNA molecule with $\mathbf{1}$ and $\mathbf{2}$ ( $\mathbf{a}$ and $\mathbf{b}$ ) in close proximity to C-28, A-29, G-30, A-31, A-38, and X-37 (Figures S15-S18). The resulting binding energies for complexes 1 and 2 ( $\mathbf{a}$ and $\mathbf{b}$ ) were found to be -283.35 , $-283.10,-285.73$, and $-285.37 \mathrm{KJ} \mathrm{mol}^{-1}$. The greater negative binding energy values for the complexes with tRNA validate their selective preferential binding propensity toward the RNA biomolecular target in concordance with the results obtained from spectroscopic studies.

\section{CONCLUSIONS}

RNA-targeted enantiomeric $N$-(2-hydroxy-1-naphthylidene) amino acid $\mathrm{Cu}$ (II) complexes $\mathbf{1}$ and $\mathbf{2}$ (a and $\mathbf{b}$ ) were synthesized possessing distorted square pyramidal geometry due to the presence of the Jahn-Teller effect. Complexes 1 and 2 ( $\mathbf{a}$ and $\mathbf{b}$ ) possess distinct chiral centers located at $\mathrm{C} 4$ ( $\mathbf{1 a}$ and $\mathbf{1 b})$ and C7 ( $\mathbf{2} \mathbf{a}$ and $\mathbf{2 b})$ carbon centers in the amino acid ligand framework. The enantiomeric discrimination of complexes $\mathbf{1}$ and $\mathbf{2}$ (a and $\mathbf{b}$ ) for the biomolecular target ctDNA/tRNA was evaluated by studying their binding profile, which indicated that complexes interact via the intercalative mode with higher binding propensity of L-enantiomers and show more avid binding with the tRNA molecule as compared to ct-DNA. SEM studies reveal the formation of different condensate morphologies upon interaction with ct-DNA/ tRNA molecules depending on the nature of the amino acid ligand framework. The cleavage experiments of $\mathrm{L}$-enantiomers with pBR322 DNA demonstrated that 1a and 2a were capable of cleaving plasmid DNA in the presence of $\mathrm{H}_{2} \mathrm{O}_{2}$, implicating lethal double-strand DNA scission mediated through Fenton's pathway. The carboxylate groups of the amino acid ligand, water molecule present in the axial site of the copper atom, or both could be responsible for promoting oxidative DNA cleavage. The mechanistic insight of DNA cleavage showed that DNA scission was facilitated in the presence of ROS radical scavengers, suggesting the involvement of singlet oxygen $\left({ }^{1} \mathrm{O}_{2}\right)$ and superoxide anions $\left(\mathrm{O}_{2}{ }^{\bullet-}\right)$. tRNA cleavage experiments of complexes $1 \mathrm{a}$ and $\mathbf{2 a}$ were performed, which revealed efficient cleaving activity of the complexes as a function of both increasing concentration and incubation time. The in vitro cytotoxicities of the enantiomeric complexes 1 and 2 (a and $\mathbf{b}$ ) were investigated against three human cancer cell lines. The most promising and significant cytotoxic activity was observed for L-enantiomeric complex 2a against the MCF-7 breast cancer cell line with a $\mathrm{GI}_{50}$ value of $<1 \mu \mathrm{M}$. The higher binding affinity and cytotoxicity of complex $2 \mathrm{a}$ were due to its higher lipophilicity, which was further validated by calculating the $\log P$ value. Molecular modeling studies also showed the stereochemical dependence of the complexes with higher energy binding values for L-enantiomeric complexes toward the tRNA molecule. The above results are valuable for the future rational design of new chiral copper-based antitumor drug candidates offering enantioselectivity toward the RNA molecule as a therapeutic target.

\section{EXPERIMENTAL SECTION}

Physical Methods. Elemental analysis was carried out on Carlo Erba Analyser Model 1106. Fourier transform infrared (FTIR) spectra were recorded on a spectrum Two (PerkinElmer) FTIR spectrometer. The EPR spectra of the copper complexes were recorded on a Varian E 112 EPR spectrometer using X-band frequency $(9.5 \mathrm{GHz})$ at room temperature. Electronic spectra were recorded on a UV-1700 PharmaSpec UV-vis spectrophotometer (Shimadzu) in $\mathrm{MeOH}$ using cuvettes of $1 \mathrm{~cm}$ path length, and collected data were reported in $\lambda_{\max } / \mathrm{nm}$. ESI-MS spectra were recorded on a Micromass Quattro II triple quadrupole mass spectrometer. Emission spectra were measured on a Shimadzu RF-5301PC Spectrofluorophotometer. Circular dichoric spectra were measured on a Jasco J-815 CD spectrometer in $\mathrm{MeOH}$ at room temperature. SEM micrographs were recorded with a JEOL JSM-6510LV scanning electron microscope (10$15 \mathrm{kV})$. The viscosity measurements were carried out using an Oswald capillary viscometer maintained at $25{ }^{\circ} \mathrm{C}$. Thermal melting experiments were carried out on a PerkinElmer Lambda 850 spectrophotometer equipped with a Peltier temperature-controlling programmer. Cleavage experiments were performed with the help of Axygen electrophoresis supported by Genei power supply $(50-500 \mathrm{~V})$ and photographed by the Vilber-INFINITY gel documentation system.

Materials. Commercially obtained chemicals and solvents were used without further purification. 2-Hydroxy-1-naphthaldehyde (Sigma-Aldrich), L/D-valine, and L/D-phenylalanine (Sigma-Aldrich), copper nitrate trihydrate (Merck), ethidium bromide (EB), tris-(hydroxymethyl)aminomethane (tris buffer) (Sigma-Aldrich), supercoiled pBR322 plasmid DNA (Genei), and $6 \times$ loading dye (Fermentas Life Science) were utilized as received. The disodium salt of ct-DNA and yeast tRNA (Type IX) from Torula yeast were purchased from Sigma Chemicals Co. and stored at $4{ }^{\circ} \mathrm{C}$.

Experiments involving the interaction studies of the complexes with ct-DNA and yeast tRNA were carried out in aerated buffer (5.0 mM Tris- $\mathrm{HCl}, 50.0 \mathrm{mM} \mathrm{NaCl}, \mathrm{pH}=7.3$ ). The concentration per base pair for both ct-DNA and tRNA was determined spectrophotometrically by considering $\varepsilon_{260} \mathrm{~nm}$ values to be 6600 and $7700 \mathrm{M}^{-1} \mathrm{~cm}^{-1}$, respectively.

Synthesis of Complexes. To the stirred solution of $\mathrm{L} / \mathrm{D}-$ valine $(0.117 \mathrm{~g}, 1 \mathrm{mmol})$ and $\mathrm{L} / \mathrm{D}$-phenylalanine $(0.165 \mathrm{~g}, 1$ $\mathrm{mmol}$ ) deprotonated in the presence of $\mathrm{KOH}(0.056 \mathrm{~g}, 1$ mmol), a methanolic solution of 2-hydoxy-1-naphthaldehyde $(0.172 \mathrm{~g}, 1 \mathrm{mmol})$ was added. The reaction mixture was kept on reflux for $3 \mathrm{~h}$ to yield a yellow solution. The completion of the reaction was monitored by using TLC. Further, the complexes were synthesized by in situ metallation after addition of $\mathrm{Cu}\left(\mathrm{NO}_{3}\right)_{2} \cdot 3 \mathrm{H}_{2} \mathrm{O}(0.241 \mathrm{~g}, 1 \mathrm{mmol})$, which subsequently results in a green solution of complexes $\mathbf{1}$ and 2 ( $\mathbf{a}$ and $\mathbf{b}$ ). The reaction mixtures were filtered and kept at room temperature. Suitable green, thin, needlelike crystals were obtained from the mother liquor after 3-4 days.

Complex $\left[\mathrm{C}_{16} \mathrm{H}_{15} \mathrm{CuNO}_{3}\right], 1 a$. Yield: $85 \%$, mp: $215^{\circ} \mathrm{C}$, anal. (\%) calcd for $\mathrm{C}_{16} \mathrm{H}_{15} \mathrm{CuNO}_{3}$ : $\mathrm{C}$ (57.74), $\mathrm{H}$ (4.54), N (4.21), found: $\mathrm{C}(57.49), \mathrm{H}(4.25), \mathrm{N}(4.35)$. FTIR $\left(\mathrm{KBr} \mathrm{cm}^{-1}\right): 1642$ $\nu(\mathrm{HC}=\mathrm{N}), 1546 \nu_{\text {asym }}(\mathrm{C}=\mathrm{O}), 1413 \nu_{\text {sym }}(\mathrm{C}=\mathrm{O}), 1247$ $\nu(\mathrm{C}-\mathrm{O}), 574 \nu(\mathrm{M}-\mathrm{O}), 479 \nu(\mathrm{M}-\mathrm{N})$. UV-vis $\left(\lambda_{\text {max }} \mathrm{nm}\right)$ in DMSO: $376\left(n-\pi^{*}\right), 646(\mathrm{~d}-\mathrm{d})$. ESI-MS $(m / z): 332.99$ $\left[\mathrm{C}_{16} \mathrm{H}_{15} \mathrm{CuNO}_{3}\right]^{+}$. 
Complex $\left[\mathrm{C}_{16} \mathrm{H}_{15} \mathrm{CuNO}_{3}\right], 16$. Yield: $83 \%$, mp: $214{ }^{\circ} \mathrm{C}$, anal. (\%) calcd for $\mathrm{C}_{16} \mathrm{H}_{15} \mathrm{CuNO}_{3}$ : $\mathrm{C}$ (57.74), $\mathrm{H}$ (4.54), $\mathrm{N}$ (4.21), found: $\mathrm{C}$ (57.64), $\mathrm{H}(4.51), \mathrm{N}$ (4.19). FTIR $\left(\mathrm{KBr} \mathrm{cm}^{-1}\right): 1641$ $\nu(\mathrm{HC}=\mathrm{N}), 1542 \nu_{\text {asym }}(\mathrm{C}=\mathrm{O}), 1414 \nu_{\text {sym }}(\mathrm{C}=\mathrm{O}), 1247$ $\nu(\mathrm{C}-\mathrm{O}), 573 \nu(\mathrm{M}-\mathrm{O}), 480 \nu(\mathrm{M}-\mathrm{N})$. UV-vis $\left(\lambda_{\max }, \mathrm{nm}\right)$ in DMSO: $375\left(n-\pi^{*}\right), 647(\mathrm{~d}-\mathrm{d})$. ESI-MS $(m / z): 332.99$ $\left[\mathrm{C}_{16} \mathrm{H}_{15} \mathrm{CuNO}_{3}\right]^{+}$.

Complex $\left[\mathrm{C}_{21} \mathrm{H}_{21} \mathrm{CuNO}_{5}\right], 2 a$. Yield: $87 \%$, mp: $228{ }^{\circ} \mathrm{C}$, anal. (\%) calcd for $\mathrm{C}_{21} \mathrm{H}_{20} \mathrm{CuNO}_{5}$ : $\mathrm{C}$ (58.53), $\mathrm{H}$ (4.91), N (3.25), found: $\mathrm{C}$ (58.59), $\mathrm{H}(4.55), \mathrm{N}$ (3.21). FTIR $\left(\mathrm{KBr} \mathrm{cm}^{-1}\right): 3470$ $\nu(-\mathrm{OH}), 1637 \nu(\mathrm{HC}=\mathrm{N}), 1568 \nu_{\text {asym }}(\mathrm{C}=\mathrm{O}), 1451$ $\nu_{\text {sym }}(\mathrm{C}=\mathrm{O}), 1247 \nu(\mathrm{C}-\mathrm{O}), 550 \nu(\mathrm{M}-\mathrm{O}), 488 \nu(\mathrm{M}-\mathrm{N})$. UV-vis $\left(\lambda_{\max }, \mathrm{nm}\right)$ in DMSO: $371\left(n-\pi^{*}\right), 655(\mathrm{~d}-\mathrm{d})$. ESIMS $(m / z): 381.01\left[\mathrm{C}_{20} \mathrm{H}_{15} \mathrm{CuNO}_{3}\right]^{+}$.

Complex $\left[\mathrm{C}_{21} \mathrm{H}_{21} \mathrm{CuNO}_{5}\right]$, 2b. Yield: $84 \%$, mp: $226{ }^{\circ} \mathrm{C}$, anal. (\%) calcd for $\mathrm{C}_{21} \mathrm{H}_{20} \mathrm{CuNO}_{5}$ : $\mathrm{C}$ (58.53), $\mathrm{H}$ (4.91), $\mathrm{N}$ (3.25), found: $\mathrm{C}$ (58.41), $\mathrm{H}(4.51), \mathrm{N}(3.22)$. FTIR $\left(\mathrm{KBr} \mathrm{cm}^{-1}\right): 3470$ $\nu(-\mathrm{OH}), 1638 \nu(\mathrm{HC}=\mathrm{N}), 1562 \nu_{\text {asym }}(\mathrm{C}=\mathrm{O}), 1449$ $\nu_{\text {sym }}(\mathrm{C}=\mathrm{O}), 1247 \nu(\mathrm{C}-\mathrm{O}), 549 \nu(\mathrm{M}-\mathrm{O}), 486 \nu(\mathrm{M}-\mathrm{N})$. UV-vis $\left(\lambda_{\max }, \mathrm{nm}\right)$ in DMSO: $389\left(n-\pi^{*}\right), 651(\mathrm{~d}-\mathrm{d})$. ESIMS $(m / z): 381.01\left[\mathrm{C}_{20} \mathrm{H}_{15} \mathrm{CuNO}_{3}\right]^{+}$.

$\mathrm{X}$-ray Diffraction Studies. Single-crystal X-ray diffraction studies of complexes $\mathbf{1}$ and $\mathbf{2}$ ( $\mathbf{a}$ and $\mathbf{b}$ ) were performed on a D8 VENTURE Bruker AXS diffractometer employing graphite monochromated Mo K $\alpha$ radiation generated from a fine focus sealed tube $(\lambda=0.71073 \AA)$ at $150 \mathrm{~K}$. The structures were solved by the dual space algorithm using the SHELXT program $^{68}$ and further refined with the full matrix least-square methods based on F2 (SHELXL). ${ }^{69}$ All non-hydrogen atoms were refined with anisotropic atomic displacement parameters. Hydrogen atoms were finally included in their calculated position. The drawings of the complexes were realized with PLATON. ${ }^{70}$ The summary of the crystallographic information for complexes $\mathbf{1}$ and $\mathbf{2}$ ( $\mathbf{a}$ and $\mathbf{b}$ ) is given in Table 1 .

Hirshfield Surface Analysis. Hirshfield surface analyses including $d_{\text {norm }}$ shape index, and curvedness of complexes 1a and $\mathbf{2 a}$ along with their $2 \mathrm{D}$ fingerplots were generated using software crystal explorer 17.5. ${ }^{71}$ The analysis was performed based on the results obtained from single-crystal X-ray diffraction studies.

Binding Studies with ct-DNA and tRNA. Interaction studies with ct-DNA and tRNA were carried out by employing absorption titration, FID assay, circular dichoric studies, and hydrodynamic measurements according to the standard methods previously adopted by our laboratory. ${ }^{72,73}$

Morphological Studies. The condensates for SEM analysis were prepared from an equimolar mixture of methanolic solution of complexes $\mathbf{1 a}$ and $\mathbf{2 a}$ and ct-DNA and tRNA (Tris- $\mathrm{HCl}$ buffer, $\mathrm{pH}=7.2$ ). The samples were airdried at room temperature for $12 \mathrm{~h}$. Before taking the SEM micrographs, the samples were coated with platinum using JEOL JFC-1600 auto fine coater at $20 \mathrm{~mA}$. The observed images were captured and saved digitally.

Cleavage Studies. The cleavage experiments of supercoiled pBR322 DNA (300 ng) in Tris- $\mathrm{HCl} / \mathrm{NaCl}(5: 50 \mathrm{mM})$ buffer at $\mathrm{pH} 7.2$ were carried out using agarose gel electrophoresis. The samples were incubated at $37{ }^{\circ} \mathrm{C}$ for 45 $\mathrm{min}$, and the cleavage activity was monitored in the presence and absence of reactive oxygen species (ROS) to study the mechanistic aspect of the cleavage pathway. tRNA cleavage experiments were performed in Tris- $\mathrm{HCl} 40 \mathrm{mM}$ buffer by incubating the reaction mixtures for 3 and $24 \mathrm{~h}$ containing increasing concentrations of complexes $\mathbf{1}$ and $\mathbf{2}$ (a and $\mathbf{b}$ ). The electrophoretic assays were carried out in Tris-borateethylenediaminetetraacetic acid buffer for $180 \mathrm{~min}$ at $50 \mathrm{~V}$ $\mathrm{cm}^{-1}$. tRNA fragments were visualized after incubation with EB (0.6 mg mL $\left.\mathrm{mL}^{-1}\right)$ using a UV transilluminator.

Partition Coefficient $(\log P)$. The values of the partition coefficient and other molecular properties of the ligands and their respective metal complexes were calculated by molinspiration software (https://www.molinspiration.com).

Cytotoxic Activity. The cell lines MCF-7, HeLa, and MIA PaCa-2 obtained from NCI, and NCCS, Pune, were grown in RPMI 1640 supplemented with $10 \%$ fetal bovine serum and 2 $\mathrm{mM}$ L-glutamine in 96-well microtiter plates and incubated at $37{ }^{\circ} \mathrm{C}, 5 \% \mathrm{CO}_{2}, 95 \%$ air, and $100 \%$ relative humidity for $24 \mathrm{~h}$. Plates were incubated for $48 \mathrm{~h}$ with different concentrations of metal complexes in culture medium. Adriamycin was also included as a positive control. Sulphorhodamine B (SRB) solution $(50 \mu \mathrm{L})$ at $0.4 \%(\mathrm{w} / \mathrm{v})$ in $1 \%$ acetic acid was added to each well and incubated for $20 \mathrm{~min}$ at room temperature. Lastly, the plates were air-dried, and the bound stain was eluted with $10 \mathrm{mM}$ trizma base. Absorbance was read at a wavelength of $540 \mathrm{~nm}$ with $690 \mathrm{~nm}$ reference wavelength. All experiments were made in triplicate, and the percent growth was calculated and expressed as the ratio of average absorbance of the test well to the average absorbance of the control wells. $^{74}$

Molecular Docking Studies. Molecular docking studies were performed using HEX 8.0 software. $^{75}$ The structures of complexes 1 and 2 ( $\mathbf{a}$ and $\mathbf{b}$ ) were converted into the PDB format prior to the docking studies. The crystal structures of $\mathrm{B}$ DNA (PDB ID: BDNA) and tRNA (PDB ID: 6TNA) were downloaded from the protein data bank (http://www.rcsb. org./pdb). Visualization of the docked pose of complexes was done using the Discovery studio molecular graphics program.

\section{ASSOCIATED CONTENT}

\section{S Supporting Information}

The Supporting Information is available free of charge on the ACS Publications website at DOI: 10.1021/acsomega.9b00131.

Experimental details, EPR spectra, ESI-MS spectra, Hirshfield surface analysis, tables for X-ray crystallographic data of complexes $\mathbf{1}$ and $\mathbf{2}$ ( $\mathbf{a}$ and $\mathbf{b}$ ), binding curves for complexes $\mathbf{1}$ and $\mathbf{2}$ (a and $\mathbf{b}$ ) with ct-DNA, cleavage of ct-DNA and tRNA, $\log P$ values, cytotoxicity data, and docking studies (PDF)

Crystallographic data (ZIP)

\section{AUTHOR INFORMATION}

\section{Corresponding Author}

*E-mail: farukh.arjmand18@gmail.com.

ORCID ${ }^{\circ}$

Farukh Arjmand: 0000-0003-4677-2682

Notes

The authors declare no competing financial interest.

\section{ACKNOWLEDGMENTS}

The authors are grateful to SAIF Panjab University, Chandigarh, for providing elemental analysis and ESI-MS facilities. We are also thankful to Department of Chemistry, Aligarh Muslim University, for providing the FTIR, UV-vis, and EPR facility. The authors also acknowledge the University 
Sophisticated Instrumentation Facility (USIF), Aligarh Muslim University, for carrying out the SEM studies. The authors are highly thankful to Anticancer Drug screening facility (ACDSF) of ACTREC, Tata Memorial Centre, Navi Mumbai, for carrying out in vitro anticancer activity of complexes by the SRB assay. The author (Siffeen Zehra) sincerely acknowledges financial support from University Grants Commission (UGC), New Delhi, for providing the fellowship and the Department of Chemistry, AMU, through UGC-assisted DRS-SAP, DSTFIST, and DST PURSE Programme.

\section{REFERENCES}

(1) Mjos, K. D.; Orvig, C. Metallodrugs in Medicinal Inorganic Chemistry. Chem. Rev. 2014, 114, 4540-4563.

(2) Rosenberg, B. Cisplatin: Its History and Possible Mechanisms of Action. Cisplatin 1980, 9-20.

(3) Gailer, J. Improving the safety of metal-based drugs by tuning their metabolism with chemoprotective agents. J. Inorg. Biochem. 2018, 179, 154-157.

(4) Hanif, M.; Hartinger, C. G. Anticancer metallodrugs: where is the next cisplatin? Future Med. Chem. 2018, 10, 615-617.

(5) Cheung-Ong, K.; Giaever, G.; Nislow, C. DNA-Damaging Agents in Cancer Chemotherapy: Serendipity and Chemical Biology. Chem. Biol. 2013, 20, 648-659.

(6) Hermann, T.; Westhof, E. RNA as a drug target: chemical, modelling, and evolutionary tools. Curr. Opin. Biotechnol. 1998, 9, $66-73$.

(7) Suseela, Y. V.; Narayanaswamy, N.; Pratihar, S.; Govindaraju, T. Far-red fluorescent probes for canonical and noncanonical nucleic acid structures: current progress and future implications. Chem. Soc. Rev. 2018, 47, 1098-1131.

(8) Petrovic, A. G.; Polavarapu, P. L. Structural Transitions in Polyriboadenylic Acid Induced by the Changes in $\mathrm{pH}$ and Temperature: Vibrational Circular Dichroism Study in Solution and Film States. J. Phys. Chem. B. 2005, 109, 23698-23705.

(9) Hermann, T. Strategies for the design of drugs targeting RNA and RNA-protein complexes. Angew. Chem., Int. Ed. 2000, 39, 18901905.

(10) Geisler, S.; Coller, J. RNA in unexpected places: long noncoding RNA functions in diverse cellular contexts. Nat. Rev. Mol. Cell Biol. 2013, 14, 699-712.

(11) Chow, C. S.; Bogdan, F. M. A Structural Basis for RNA-Ligand Interactions. Chem. Rev. 1997, 97, 1489-1513.

(12) Warner, K. D.; Hajdin, C. E.; Weeks, K. M. Principles for targeting RNA with drug-like small molecules. Nat. Rev. Drug Discovery 2018, 17, 547-558.

(13) Thomas, J. R.; Hergenrother, P. J. Targeting RNA with small molecules. Chem. Rev. 2008, 108, 1171-1224.

(14) Aboul-ela, F. Strategies for the design of RNA-binding small molecules. Future Med. Chem. 2010, 2, 93-119.

(15) Guan, L.; Disney, M. D. Recent advances in developing small molecules targeting RNA. ACS Chem. Biol. 2012, 7, 73-86.

(16) Wagner, A. J.; Zubarev, D. Y.; Aspuru-Guzik, A.; Blackmond, D. G. Chiral Sugars Drive Enantioenrichment in Prebiotic Amino Acid Synthesis. ACS Cent. Sci. 2017, 3, 322-328.

(17) McConathy, J.; Owens, M. J. Stereochemistry in Drug Action. Prim. Care Companion J. Clin. Psychiatry 2003, 5, 70-73.

(18) Cayen, M. N. Racemic mixtures and single stereoisomers: Industrial concerns and issues in drug development. Chirality 1991, 3, 94-98.

(19) Malik, M. A.; Dar, O. A.; Gull, P.; Wani, M. Y.; Hashmi, A. A. Heterocyclic Schiff base transition metal complexes in antimicrobial and anticancer chemotherapy. MedChem Comm 2018, 9, 409-436.

(20) Qiao, X.; Ma, Z.-Y.; Xie, C.-Z.; Xue, F.; Zhang, Y.-W.; Xu, J.-Y.; Qiang, Z.-Y.; Lou, J.-S.; Chen, G.-J.; Yan, S.-P. Study on potential antitumor mechanism of a novel Schiff Base copper(II) complex: Synthesis, crystal structure, DNA binding, cytotoxicity and apoptosis induction activity. J. Inorg. Biochem. 2011, 105, 728-737.
(21) Ren, S.; Wang, R.; Komatsu, K.; Krause, P. B.; Zyrianov, Y.; McKenna, C. E.; Csipke, C.; Tokes, Z. A.; Lien, E. J. Synthesis, Biological Evaluation, and Quantitative Structure-Activity Relationship Analysis of New Schiff Bases of Hydroxysemicarbazide as Potential Antitumor Agents. J. Med. Chem. 2002, 45, 410-419.

(22) Chauhan, M.; Banerjee, K.; Arjmand, F. DNA Binding Studies of Novel Copper(II) Complexes Containing L-Tryptophan as Chiral Auxiliary: In Vitro Antitumor Activity of $\mathrm{Cu}-\mathrm{Sn}_{2}$ Complex in Human Neuroblastoma Cells. Inorg. Chem. 2007, 46, 3072-3082.

(23) Kumaravel, G.; Utthra, P. P.; Raman, N. Exploiting the biological efficacy of benzimidazole based Schiff base complexes with L-Histidine as a co-ligand: Combined molecular docking, DNA interaction, antimicrobial and cytotoxic studies. Bioorg. Chem. 2018, $77,269-279$.

(24) Yousuf, I.; Arjmand, F.; Tabassum, S.; Toupet, L.; Khan, R. A.; Siddiqui, M. A. Mechanistic insights into a novel chromone appended $\mathrm{Cu}$ (II) anticancer drug entity: in vitro binding profile with DNA/ RNA substrates and cytotoxic activity against MCF-7 and HepG2 cancer cells. Dalton Trans. 2015, 44, 10330-10342.

(25) Arjmand, F.; Jamsheera, A.; Afzal, M.; Tabassum, S. Enantiomeric Specificity of Biologically Significant $\mathrm{Cu}$ (II) and $\mathrm{Zn}$ (II) Chromone Complexes Towards DNA. Chirality 2012, 24, 977-986.

(26) Neelakantan, M. A.; Balamurugan, K.; Balakrishnan, C.; Subha, L. Interaction of Amino Acid Schiff Base Metal Complexes with DNA/BSA Protein and Antibacterial Activity: Spectral Studies, DFT Calculations and Molecular Docking Simulations. Appl. Organomet. Chem. 2018, 32, No. e4259.

(27) Colak, A.; Terzi, Ü.; Col, M.; Karaoglu, Ş. A.; Karaböcek, S.; Küçükdumlu, A.; Ayaz, F. A. DNA binding, antioxidant and antimicrobial activities of homo- and heteronuclear copper(II) and nickel(II) complexes with new oxime-type ligands. Eur. J. Med. Chem. 2010, 45, 5169-5175.

(28) Turski, M. L.; Thiele, D. J. New Roles for Copper Metabolism in Cell Proliferation, Signaling, and Disease. J. Biol. Chem. 2009, 284, $717-721$.

(29) Shi, X.; Chen, Z.; Wang, Y.; Guo, Z.; Wang, X. Hypotoxic copper complexes with potent anti-metastatic and anti-angiogenic activities against cancer cells. Dalton Trans. 2018, 47, 5049-5054.

(30) Marzano, C.; Pellei, M.; Tisato, F.; Santini, C. Copper Complexes as Anticancer Agents. Anti-Cancer Agents Med. Chem. 2009, 9, 185-211.

(31) Denoyer, D.; Masaldan, S.; Fontaine, S. L.; Cater, M. A. Targeting copper in cancer therapy: 'Copper That Cancer'. Metallomics 2015, 7, 1459-1476.

(32) Tardito, S.; Bassanetti, I.; Bignardi, C.; Elviri, L.; Tegoni, M.; Mucchino, C.; Bussolati, O.; Gazzola, R. F.; Marchiò, L. Copper Binding Agents Acting as Copper Ionophores Lead to Caspase Inhibition and Paraptotic Cell Death in Human Cancer Cells. J. Am. Chem. Soc. 2011, 133, 6235-6242.

(33) Zuo, J.; Bi, C.; Fan, Y.; Buac, D.; Nardon, C.; Daniel, K. G.; Dou, Q. P. Cellular and computational studies of proteasome inhibition and apoptosis induction in human cancer cells by amino acid Schiff base-copper complexes. J. Inorg. Biochem. 2013, 118, 8393.

(34) Ng, C. H.; Kong, S. M.; Tiong, Y. L.; Maah, M. J.; Sukram, N.; Ahmad, M.; Khoo, A. S. B. Selective anticancer copper(II)-mixed ligand complexes: targeting of ROS and proteasomes. Metallomics 2014, 6, 892-906.

(35) Liu, Z. C.; Wang, B. D.; Li, B.; Wang, Q.; Yang, Z. Y.; Li, T. R.; $\mathrm{Li}, \mathrm{Y}$. Crystal structures, DNA-binding and cytotoxic activities studies of $\mathrm{Cu}$ (II) complexes with 2-oxoquinoline-3-carbaldehyde Schiff-bases. Eur. J. Med. Chem. 2010, 45, 5353-5361.

(36) Meadows, K. A.; Liu, F.; Sou, J.; Hudson, B. P.; McMillin, D. R. Spectroscopic and Photophysical Studies of the Binding Interactions between Copper Phenanthroline Complexes and RNA. Inorg. Chem. 1993, 32, 2919-2923.

(37) Reddy, P. R.; Shilpa, A.; Raju, N.; Raghavaiah, P. Synthesis, structure, DNA binding and cleavage properties of ternary amino acid 
Schiff base-phen/bipy $\mathrm{Cu}(\mathrm{II})$ complexes. J. Inorg. Biochem. 2011, 105, 1603-1612.

(38) Barve, A.; Kumbhar, A.; Bhat, M.; Joshi, B.; Butcher, R.; Sonawane, U.; Joshi, R. Mixed-Ligand Copper(II) Maltolate Complexes: Synthesis, Characterization, DNA Binding and Cleavage, and Cytotoxicity. Inorg. Chem. 2009, 48, 9120-9132.

(39) Yang, C.-T.; Vetrichelvan, M.; Yang, X.; Moubaraki, B.; Murray, K. S.; Vittal, J. J. Syntheses, structural properties and catecholase activity of copper(II) complexes with reduced Schiff base N- (2hydroxybenzyl)-amino acids. Dalton Trans. 2004, 113-121.

(40) Ramakrishnan, S.; Rajendiran, V.; Palaniandavar, M.; Periasamy, V. S.; Srinag, B. S.; Krishnamurthy, H.; Akbarsha, M. A. Induction of Cell Death by Ternary Copper(II) Complexes of LTyrosine and Diimines: Role of Coligands on DNA Binding and Cleavage and Anticancer Activity. Inorg. Chem. 2009, 48, 1309-1322.

(41) Zhou, X.-Q.; Sun, Q.; Jiang, L.; Li, S. T.; Gu, W.; Tian, J.-L.; Liu, X.; Yan, S.-P. Synthesis, characterization, DNA/BSA interactions and anticancer activity of achiral and chiral copper complexes. Dalton Trans. 2015, 44, 9516-9527.

(42) Addison, A. W.; Rao, T. N.; Reedijk, J.; Rijn, J.; Verschoor, G. C. Synthesis, structure, and spectroscopic properties of copper(II) compounds containing nitrogen-sulphur donor ligands; the crystal and molecular structure of aqua[1,7-bis(N-methylbenzimidazol-2'yl)-2,6-dithiaheptane]copper(II) perchlorate. J. Chem. Soc., Dalton Trans. 1984, 0, 1349-1356.

(43) Zhou, X.-Q.; Li, Y.; Zhang, D.-Y.; Nie, Y.; Li, Z.-J.; Gu, W.; Liu, X.; Tian, J.-L.; Yan, S.-P. Copper complexes based on chiral Schiffbase ligands: DNA/BSA binding ability, DNA cleavage activity, cytotoxicity and mechanism of apoptosis. Eur. J. Med. Chem. 2016, $114,244-256$.

(44) Zhang, H.-Y.; Wang, W.; Chen, H.; Zhang, S.-H.; Li, Y. Five novel dinuclear copper(II) complexes: Crystal structures, properties, Hirshfeld surface analysis and vitro antitumor activity study. Inorg. Chim. Acta 2016, 453, 507-515.

(45) Erxleben, A. Interactions of copper complexes with nucleic acids. Coord. Chem. Rev. 2018, 360, 92-121.

(46) Alagesan, M.; Bhuvanesh, N. S. P.; Dharmaraj, N. Potentially cytotoxic new copper(II) hydrazone complexes: synthesis, crystal structure and biological properties. Dalton Trans. 2013, 42, 72107223

(47) Aneesrahman, K. N.; Rohini, G.; Bhuvanesh, N. S. P.; Sundararaj, S.; Musthafa, M.; Sreekanth, A. In Vitro Biomolecular Interaction Studies and Cytotoxic Activities of Newly Synthesised Copper(II) Complexes Bearing 2-Hydroxynaphthaldehyde-Based Thiosemicarbazone. ChemistrySelect 2018, 3, 8118-8130.

(48) Koley, M. K.; Parsekar, S. U.; Duraipandy, N.; Kiran, M. S.; Varghese, B.; Manoharan, P. T.; Koley, A. P. DNA binding and cytotoxicity of two $\mathrm{Cu}$ (II) complexes containing a Schiff base ligand along with 1,10-phenanthroline or imidazole as a coligand. Inorg. Chim. Acta 2018, 478, 211-221.

(49) Liang, X.; Zou, X.; Tan, L.; Zhu, W. Study on nucleic acid (CTDNA and yeast tRNA) binding behaviors and cytotoxic properties of a heterodinuclear $\mathrm{Ru}(\mathrm{II})-\mathrm{Co}(\mathrm{III})$ polypyridyl complex. J. Inorg. Biochem. 2010, 104, 1259-1266.

(50) Hormann, J.; Malina, J.; Lemke, O.; Hülsey, M. J.; Wedepohl, S.; Potthoff, J.; Schmidt, C.; Ott, I.; Keller, B. G.; Brabec, V.; Kulak, N. Multiply Intercalator-Substituted $\mathrm{Cu}(\mathrm{II})$ Cyclen Complexes as DNA Condensers and DNA/RNA. Synthesis Inhibitors. Inorg. Chem. 2018, 57, 5004-5012.

(51) Zhao, X.-L.; Han, M.-J.; Zhang, A.-G.; Wang, K.-Z. DNA- and RNA binding and enhanced DNA-photocleavage properties of a ferrocenyl-containing ruthenium(II) complex. J. Inorg. Biochem. 2012, 107, 104-110.

(52) Facchin, G.; Kremer, E.; Barrio, D. A.; Etcheverry, S. B.; CostaFilho, A. J.; Torre, M. H. Interaction of $\mathrm{Cu}$-dipeptide complexes with Calf Thymus DNA and antiproliferative activity of [Cu(ala-phe)] in osteosarcoma-derived cells. Polyhedron 2009, 28, 2329-2334.

(53) Chikira, M. DNA-fiber EPR spectroscopy as a tool to study DNA-metal complex interactions: DNA binding of hydrated $\mathrm{Cu}$ (II) ions and $\mathrm{Cu}(\mathrm{II})$ complexes of amino acids and peptides. J. Inorg. Biochem. 2008, 102, 1016-1024.

(54) Chikira, M.; Inoue, M.; Nagane, R.; Harada, W.; Shindo, H. How amino acids control the binding of $\mathrm{Cu}$ (II) ions to DNA (II): Effect of basic amino acid residues and the chirality on the orientation of the complexes. J. Inorg. Biochem. 1997, 66, 131-139.

(55) Nagane, R.; Chikira, M.; Oumi, M.; Shindo, H.; Antholine, W. E. How amino acids control the binding of $\mathrm{Cu}$ (II) ions to DNA Part III. A novel interaction of a histidine complex with DNA. J. Inorg. Biochem. 2000, 78, 243-249.

(56) Malina, J.; Farrell, N. P.; Brabec, V. Substitution-Inert Trinuclear Platinum Complexes Efficiently Condense/Aggregate Nucleic Acids and Inhibit Enzymatic Activity. Angew. Chem., Int. Ed. 2014, 53, 12812-12816.

(57) Pinto, M. F. V.; Moran, M. C.; Miguel, M. G.; Lindman, B.; Jurado, A. S.; Pais, A. A. C. C. Controlling the Morphology in DNA Condensation and Precipitation. Biomacromolecules 2009, 10, 13191323.

(58) Toshio, I.; Satoru, K.; Takahiro, S.; Kenichi, Y.; Sergey, S. S. Competition between compaction of single chains and bundling of multiple chains in giant DNA molecules. J. Chem. Phys. 2004, 120, 4004-4011.

(59) Philippova, O. E.; Akitaya, T.; Mullagaliev, I. R.; Khokhlov, A. R.; Yoshikawa, K. Salt-Controlled Intrachain/Interchain Segregation in DNA Complexed with Polycation of Natural Origin. Macromolecules 2005, 38, 9359-9365.

(60) Pereira, P.; Jorge, A. F.; Martins, R.; Pais, A. A. C. C.; Sousa, F.; Figueiras, A. Characterization of polyplexes involving small RNA. J. Colloid Interface Sci. 2012, 387, 84-94.

(61) González-Álvarez, M.; Alzuet, G.; Borrás, J.; Macías, B.; Castiñeiras, A. Oxidative Cleavage of DNA by a New Ferromagnetic Linear Trinuclear Copper(II) Complex in the Presence of $\mathrm{H}_{2} \mathrm{O}_{2} /$ Sodium Ascorbate. Inorg. Chem. 2003, 42, 2992-2998.

(62) Jin, Y.; Cowan, J. A. DNA Cleavage by Copper-ATCUN Complexes. Factors Influencing Cleavage Mechanism and Linearization of dsDNA. J. Am. Chem. Soc. 2005, 127, 8408-8415.

(63) Lönnberg, H. Cleavage of RNA phosphodiester bonds by small molecular entities: a mechanistic insight. Org. Biomol. Chem. 2011, 9, $1687-1703$.

(64) Arjmand, F.; Yousuf, I.; Hadda, T. B.; Toupet, L. Synthesis, crystal structure and antiproliferative activity of $\mathrm{Cu}(\mathrm{II})$ nalidixic acid$\mathrm{DACH}$ conjugate: Comparative in vitro DNA/RNA binding profile, cleavage activity and molecular docking studies. Eur. J. Med. Chem. 2014, 81, 76-88.

(65) Mahendiran, D.; Amuthakala, S.; Bhuvanesh, N. S. P.; Kumar, R. S.; Rahiman, A. K. Copper complexes as prospective anticancer agents: in vitro and in vivo evaluation, selective targeting of cancer cells by DNA damage and S phase arrest. RSC Adv. 2018, 8, 1697316990.

(66) Zhang, C.; Maddelein, M.-L.; Sun, R. W.-Y.; Gornitzka, H.; Cuvillier, O.; Hemmert, C. Pharmacomodulation on Gold-NHC complexes for anticancer applications - is lipophilicity the key point? Eur. J. Med. Chem. 2018, 157, 320-332.

(67) Gilad, Y.; Senderowitz, H. Docking Studies on DNA Intercalators. J. Chem. Inf. Model. 2014, 54, 96-107.

(68) Sheldrick, G. M. SHELXT - Integrated space-group and crystal structure determination. Acta Cryst. 2015, A71, 3-8.

(69) Sheldrick, G. M. Crystal structure refinement with SHELXL. Acta Crystallogr., Sect. C: Struct. Chem. 2015, C71, 3-8.

(70) Spek, A. L. PLATON Procedure, A Multipurpose Crystallographic Tool; Utrecht University: Utrecht, The Netherlands, 1998.

(71) Spackman, M. A.; Jayatilaka, D. Hirshfeld surface analysis. Cryst. Eng. Comm. 2009, 11, 19-32.

(72) Arjmand, F.; Muddassir, M.; Zaidi, Y.; Ray, D. Design, synthesis and crystal structure determination of dinuclear copper-based potential chemotherapeutic drug entities: in vitro DNA binding, cleavage studies and an evaluation of genotoxicity by micronucleus test and comet assay. MedChem Comm 2013, 4, 394-405. 
(73) Lakowicz, J. R.; Webber, G. Quenching of Fluorescence by Oxygen. A Probe for Structural Fluctuations in Macromolecules. Biochemistry 1973, 12, 4161-4170.

(74) Macindoe, G.; Mavridis, L.; Venkatraman, V.; Devignes, M. D.; Ritchie, D. W. Hex Server: an FFT-based protein docking server powered by graphics processors. Nucleic Acids Res. 2010, 38, W445W449.

(75) Vichai, V.; Kirtikara, K. Sulforhodamine B colorimetric assay for cytotoxicity screening. Nat. Protoc. 2006, 1, 1112-1116. 